Prepared in cooperation with the U.S. Department of Energy, National Nuclear Security Administration Nevada Site Office, Office of Environmental Management, under Interagency Agreement DE-NA0001654

\title{
Documentation of Single-Well Aquifer Tests and Integrated Borehole Analyses, Pahute Mesa and Vicinity, Nevada
}

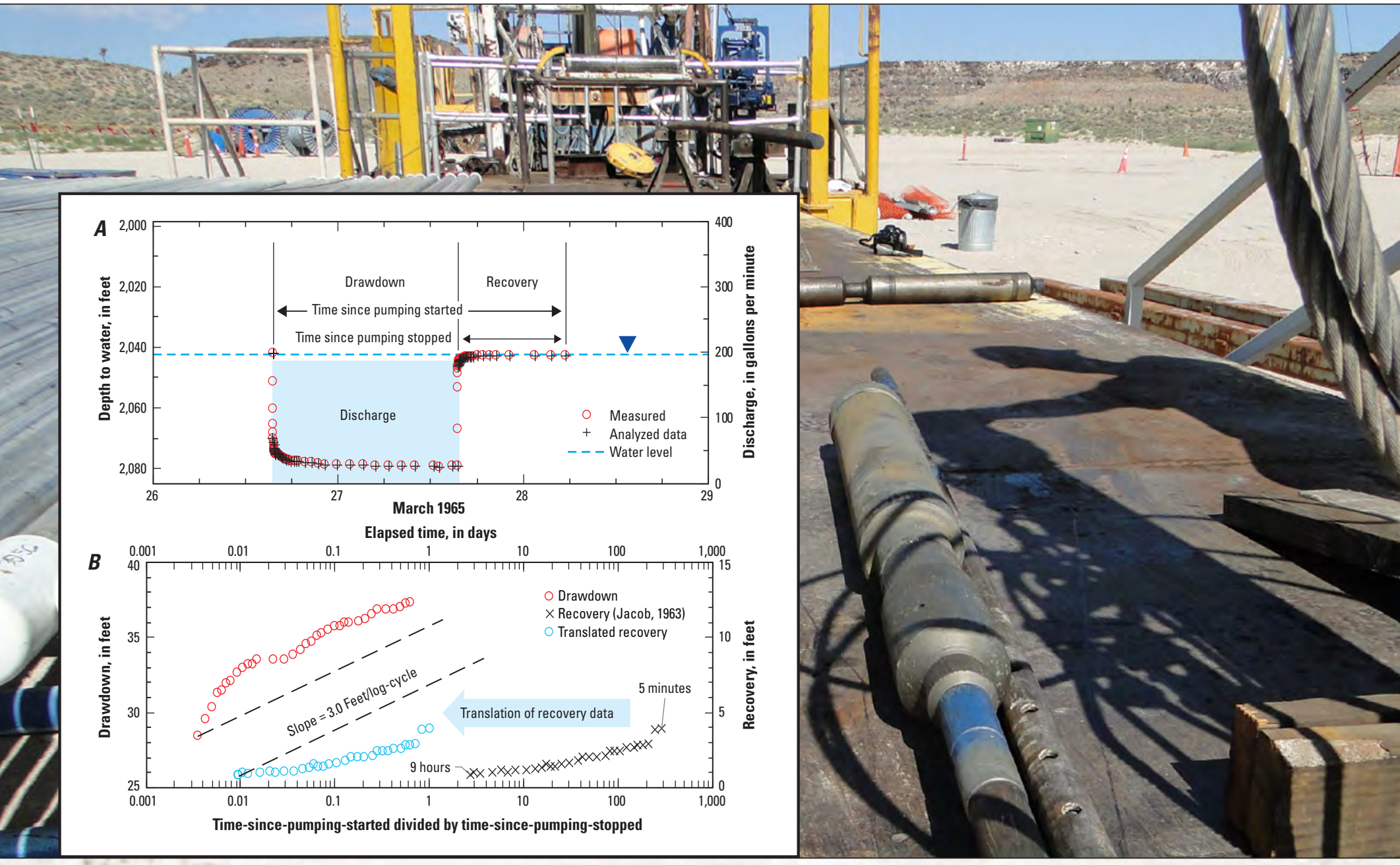

Scientific Investigations Report 2018-5096

U.S. Depar ment of the Int

U.S. Geolog cal Survey 


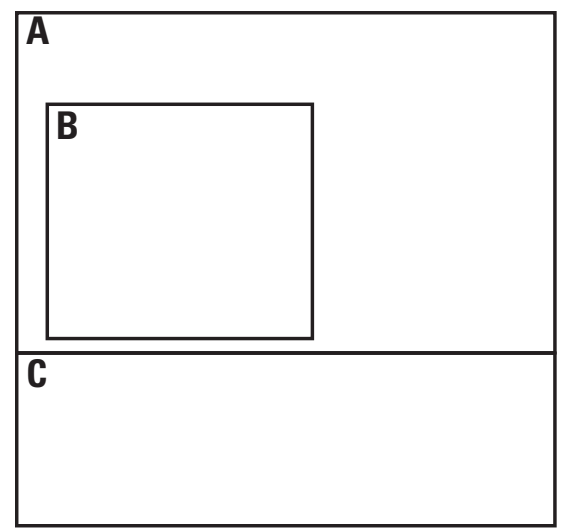

\section{FRONT COVER:}

A Photograph showing removed bridge plug for well ER-20-8.

Photograph by Robert Goodwin, Navarro Research and Engineering, Inc.

B: Graph showing examples of pumping test results from well UE-19gs (2650-4508 ft) for March 1965.

C: Photograph showing removed bridge plug for well ER-20-8.

Photograph by Robert Goodwin, Navarro Research and Engineering, Inc.

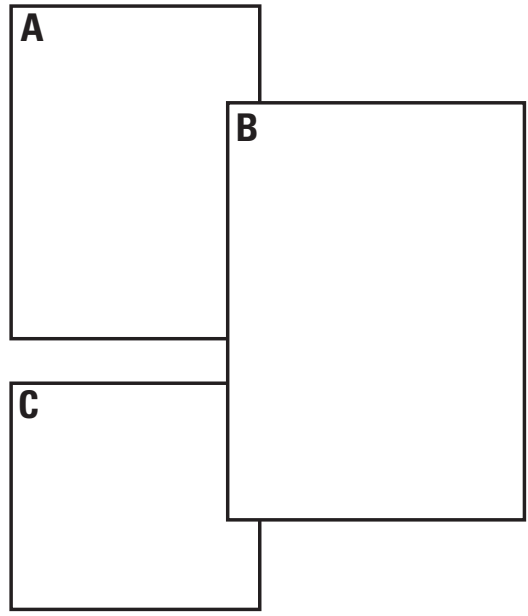

BACK COVER:

A: Photograph showing new bridge plug for well ER-20-8.

Photograph by Robert Goodwin, Navarro Research and Engineering, Inc.

B: Photograph showing upper straddle packer with crossover connected for well ER-20-8.

Photograph by Todd Gurnee, Navarro Research and Engineering, Inc.

C: Photograph showing crossover for upper straddle packer for well ER-20-8.

Photograph by Todd Gurnee, Navarro Research and Engineering, Inc. 


\section{Documentation of Single-Well Aquifer Tests and Integrated Borehole Analyses, Pahute Mesa and Vicinity, Nevada}

By Rebecca J. Frus and Keith J. Halford

Prepared in cooperation with the U.S. Department of Energy, National

Nuclear Security Administration Nevada Site Office, Office of Environmental

Management, under Interagency Agreement, DE-NA0001654

Scientific Investigations Report 2018-5096 


\section{U.S. Department of the Interior \\ RYAN K. ZINKE, Secretary}

\section{U.S. Geological Survey James F. Reilly II, Director}

\section{U.S. Geological Survey, Reston, Virginia: 2018}

For more information on the USGS - the Federal source for science about the Earth, its natural and living resources, natural hazards, and the environment-visit https://www.usgs.gov or call 1-888-ASK-USGS.

For an overview of USGS information products, including maps, imagery, and publications, visit https://store.usgs.gov.

Any use of trade, firm, or product names is for descriptive purposes only and does not imply endorsement by the U.S. Government.

Although this information product, for the most part, is in the public domain, it also may contain copyrighted materials as noted in the text. Permission to reproduce copyrighted items must be secured from the copyright owner.

Suggested citation:

Frus, R.J., and Halford, K.J., 2018, Documentation of single-well aquifer tests and integrated borehole analyses, Pahute Mesa and Vicinity, Nevada: U.S. Geological Survey Scientific Investigations Report 2018-5096, 22 p., https://doi.org/10.3133/sir20185096. 


\section{Contents}

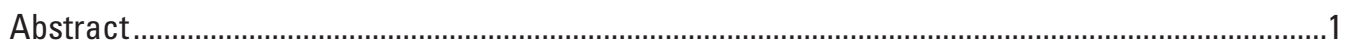

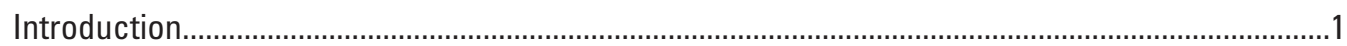

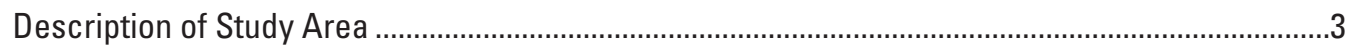

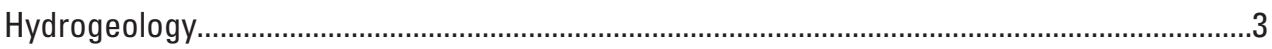

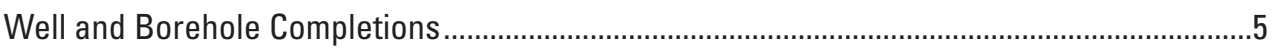

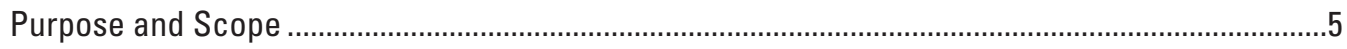

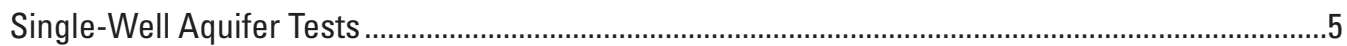

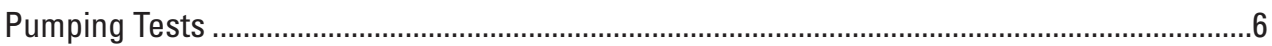

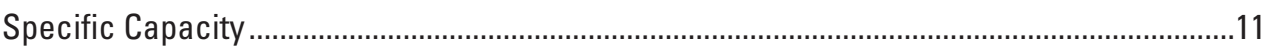

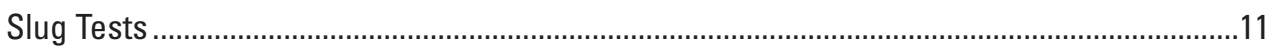

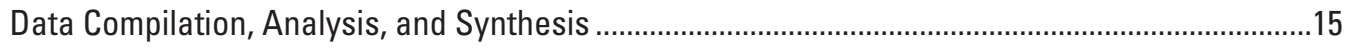

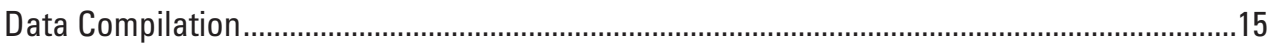

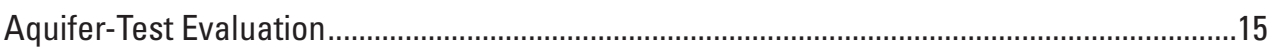

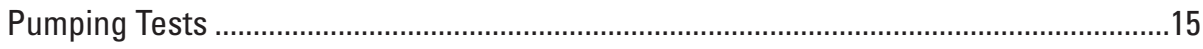

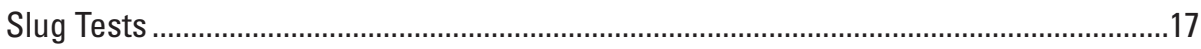

Single-Well Aquifer-Test Synthesis .............................................................................17

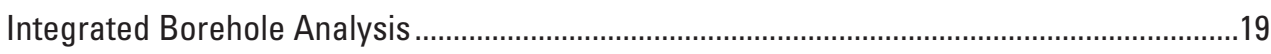

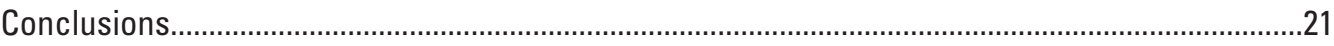

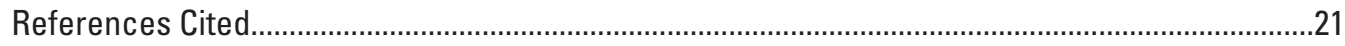

\section{Figures}

1. Map showing geographic features and single-well aquifer test borehole locations on Pahute Mesa and vicinity, Nevada ...............................................................

2. Graphs showing examples of pumping test results in well UE-19gs (2650-4508 ft) from March 1965 .......................................................................................................

3. Image showing an example of a standardized Microsoft Exce $\left.\right|^{\circledR}$ workbook for simultaneously interpreting drawdown and recovery from constant-rate

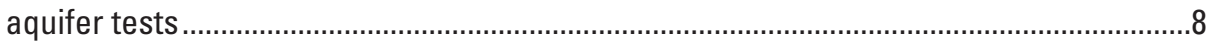

4. Graphs showing the estimated effects of water withdrawal and thermal expansion on measured water levels in well $U-19 d 2$, for which measured temperatures of discharge ranged between 86 and 114 degrees Fahrenheit, June 1964

5. Cartesian plot showing the relation between specific capacity and transmissivity from aquifer-test results at Pahute Mesa and vicinity.....

6. Cartesian plot showing changes to water level over time in well UE-18r (3442-3642 ft)

7. Image showing an example of a standardized Microsoft Exce ${ }^{\circledR}$ workbook for interpreting recovery from slug tests

8. Graphs showing example using a Bouwer and Rice (1976) analytical solution to estimate hydraulic properties from consecutive multiple slug tests in well UE-18r (3208-3408 ft), February 2, 1968.

9. Image showing an example of integrated interpretation of transmissivity estimates from multiple slug tests and pumping aquifer test in borehole $U$-19d2. 


\section{Tables}

1. Data and analytical solution quality criteria for pumping tests ........................................16

2. Data and analytical solution quality criteria for slug tests ...............................................16

\section{Conversion Factors}

U.S. customary units to International System of Units

\begin{tabular}{|c|c|c|}
\hline Multiply & By & To obtain \\
\hline \multicolumn{3}{|c|}{ Length } \\
\hline inch (in.) & 2.54 & centimeter $(\mathrm{cm})$ \\
\hline inch (in.) & 25.4 & millimeter (mm) \\
\hline foot $(\mathrm{ft})$ & 0.3048 & meter $(\mathrm{m})$ \\
\hline mile (mi) & 1.609 & kilometer (km) \\
\hline \multicolumn{3}{|c|}{ Area } \\
\hline acre & 4,047 & square meter $\left(\mathrm{m}^{2}\right)$ \\
\hline acre & 0.004047 & square kilometer $\left(\mathrm{km}^{2}\right)$ \\
\hline square foot $\left(\mathrm{ft}^{2}\right)$ & 929.0 & square centimeter $\left(\mathrm{cm}^{2}\right)$ \\
\hline square foot $\left(\mathrm{ft}^{2}\right)$ & 0.09290 & square meter $\left(\mathrm{m}^{2}\right)$ \\
\hline \multicolumn{3}{|c|}{ Volume } \\
\hline gallon (gal) & 3.785 & liter $(\mathrm{L})$ \\
\hline gallon (gal) & 0.003785 & cubic meter $\left(\mathrm{m}^{3}\right)$ \\
\hline million gallons (Mgal) & 3,785 & cubic meter $\left(\mathrm{m}^{3}\right)$ \\
\hline acre-foot (acre-ft) & 1,233 & cubic meter $\left(\mathrm{m}^{3}\right)$ \\
\hline \multicolumn{3}{|c|}{ Flow rate } \\
\hline acre-foot per year (acre-ft/yr) & 1,233 & cubic meter per year $\left(\mathrm{m}^{3} / \mathrm{yr}\right)$ \\
\hline \multicolumn{3}{|c|}{ Hydraulic conductivity } \\
\hline foot per day (ft/d) & 0.3048 & meter per day $(\mathrm{m} / \mathrm{d})$ \\
\hline \multicolumn{3}{|c|}{ Transmissivity } \\
\hline foot squared per day $\left(\mathrm{ft}^{2} / \mathrm{d}\right)$ & 0.09290 & meter squared per day $\left(\mathrm{m}^{2} / \mathrm{d}\right)$ \\
\hline
\end{tabular}

\section{Datum}

Vertical coordinate information is referenced to the National Geodetic Vertical Datum of 1929 (NGVD 29).

Horizontal coordinate information is referenced to the North American Datum of 1983 (NAD 83). Altitude, as used in this report, refers to distance above the vertical datum. 


\section{Supplemental Information}

Transmissivity: The standard unit for transmissivity is cubic foot per day per square foot times foot of aquifer thickness $\left(\left[\mathrm{ft}^{3} / \mathrm{d}\right] / \mathrm{ft}^{2}\right) \mathrm{ft}$. In this report, the mathematically reduced form, foot squared per day $\left(\mathrm{ft}^{2} / \mathrm{d}\right)$, is used for convenience.

\section{Abbreviations}

$\begin{array}{ll}\text { DOE } & \text { U.S. Department of Energy } \\ \text { NNSS } & \text { Nevada National Security Site } \\ \text { UGTA } & \text { Underground Test Area } \\ \text { USGS } & \text { U.S. Geological Survey }\end{array}$





\title{
Documentation of Single-Well Aquifer Tests and Integrated Borehole Analyses, Pahute Mesa and Vicinity, Nevada
}

\author{
By Rebecca J. Frus and Keith J. Halford
}

\section{Abstract}

Single-well aquifer testing has been carried out at Pahute Mesa in southern Nevada since 1962. These tests include single-well pumping and slug tests to estimate geologic formation hydraulic properties. Initially, aquifer tests focused on identifying low-permeability rocks suitable for testing large-yield nuclear devices, whereas later hydrologic investigations focused on potential subsurface transport of radionuclides away from Pahute Mesa.

The number of single-well aquifer tests analyzed for Pahute Mesa and vicinity was much greater than the number of actual tests because each response to a waterlevel displacement was interpreted multiple times using different analytical models by different investigators, which were reported as distinct, individual aquifer tests. Some aquifer tests also were reinterpreted multiple times because the wells had not been defined uniquely. Previous databases and reports identified wells by different borehole names, reported various depths to top and bottom of open intervals, and used inconsistent wetted-aquifer thicknesses, which were coupled with inappropriate analytical methods to interpret aquifer-test data.

This work standardized the reporting of single-well aquifer-test results at Pahute Mesa and vicinity. A hydraulicparameter database was created that uniquely identifies tested wells, reports all replicated aquifer tests in each well, and identifies the best transmissivity estimate for each well. Datasets, interpreted models, and results from 1,459 analyses are presented and evaluated for 360 unique wells.

Integrated borehole analyses were used to estimate hydraulic conductivity by depth in Pahute Mesa because vertical variations in hydraulic conductivity greatly affect groundwater velocities, which directly affect subsurface transport rates and directions. The integrated analyses reconciled differences between transmissivity estimated from pumping tests and the summed transmissivity from straddle-packer slug tests done at different depth intervals in a borehole. An integration borehole database was created that presents integrated aquifer-test results from 17 boreholes.

\section{Introduction}

Aquifer testing has been done at Pahute Mesa since 1962. Nineteen exploratory boreholes were drilled and tested between 1962 and 1968 primarily to identify lowpermeability rocks suitable for testing large-yield nuclear devices underground (Blankennagel and Weir, 1973). During this time, hydraulic properties were estimated from flow logs and by aquifer tests that pumped from total boreholes as well as by slug tests in packer-isolated sections of the boreholes. This resulted in reporting more than 400 individual tests for more than 300 uniquely identified wells (Wood, 2007). These hydraulic data were used to map suitable testing areas across Pahute Mesa, where 82 underground nuclear tests were carried out from 1965 to 1992 (U.S. Department of Energy, 2015). Results of these tests were also used to identify areas with permeable rocks that could be used for water supply (Blankennagel and Weir, 1973).

Potential subsurface transport of radionuclides from Pahute Mesa to downgradient areas outside of the Nevada National Security Site (NNSS) prompted additional hydrologic investigations after 1987 (Kilroy and Savard, 1996). These investigations focused on the fate and transport of radionuclides, which is of concern to the U.S. Department of Energy (DOE), U.S. Department of Defense (DOD), and agencies in the State of Nevada (State of Nevada and others, 1996). The U.S. Department of Energy National Nuclear Security Administration Nevada Site Office established the Underground Test Area (UGTA) program in 1996 to address these concerns. More than 40 wells have been completed to support the UGTA activities at Pahute Mesa. 
Aquifer testing has been a critical component of the UGTA activities at Pahute Mesa because groundwater-flow rates and directions are largely dependent on hydraulic property distributions. More than 30 aquifer tests have resulted from the UGTA activities. Of these, 17 tests were analyzable as multiple-well aquifer tests (Garcia and others, 2011; Garcia and others, 2017) whereas the remaining were analyzable as single-well aquifer tests. Aquifer-test data have been made available through cooperative studies between the U.S Geological Survey (USGS) and the DOE to support the UGTA activities since 2002 (Wood, 2007; Elliott and Fenelon, 2010). Associated water-level measurements, site characteristics, and well-construction information are available from the National Water Information System (NWIS) database (U.S. Geological Survey, 2018a).

The UGTA activities produced reasonable estimates of total transmissivity (or depth-integrated hydraulic conductivity) near tested wells. Vertical variations in hydraulic conductivity, which directly affect groundwater transport rates and directions (Konikow, 2010), remain poorly defined, however. Aquifer-test data from Blankennagel and Weir (1973) are suited for estimating vertical variations in hydraulic conductivity beneath Pahute Mesa because between 7 and 28 discrete 200 feet (ft) intervals were slug-tested in 17 of 27 boreholes. Each slug test involved isolating an interval with a packer, injecting about 700 gallons of water, and measuring water-level declines with a wireline (Blankennagel, 1967). Original interpretations were limited to estimates of relative specific capacities, which were sufficient for identifying rocks favorable for the construction of chambers in emplacement holes for nuclear testing. Estimating vertical variations in hydraulic conductivity required re-evaluation of the data following a subsequent development of relevant analytical solutions, such as Bouwer-Rice (Bouwer and Rice, 1976) and the Kansas Geological Survey (Butler and Garnett, 2000).

The UGTA investigators estimated vertical variations in hydraulic conductivity and total transmissivity around pumped wells at Pahute Mesa by reinterpreting historical aquifer-test data. Most hydraulic conductivity estimates for the Phase 1 investigation of Pahute Mesa were derived from the reinterpretation of 7 pumping tests and 237 slug tests (StollerNavarro Joint Venture, 2004, appendix C). Of the 7 pumping tests and 24 slug tests, 4 were reinterpreted concurrently by USGS investigators and reported independently (Belcher and others, 2001) and on the Nevada aquifer-tests Web page at https://nevada.usgs.gov/aquifertests.

Aquifer tests were interpreted multiple times because each response to a water-level displacement was interpreted by multiple analytical models, and repeated tests were considered individual (rather than replicate) aquifer tests. The UGTA investigators frequently interpreted a slug test with three to four analytical models and reported the results separately, rather than reporting a result from a single analytical solution that conformed to a conceptual model of the tested interval.
Repeated slug tests in a single well also were reported as separate tests by some UGTA investigators.

Alternatively, USGS investigators interpreted replicated tests as a single test with all data presented and evaluated simultaneously. Field records for the aquifer tests indicated that repeated slug tests were not intended to be interpreted as individual tests; they were only repeated when a completed test was judged to be questionable by the test operators. Blankennagel (1967) states on page 45, "If there is any question of leakage, the packers are reseated a few feet in either direction, and the test is rerun."

The apparent number of investigated sites has been inflated greatly and is difficult to track if the repeated interpretations described earlier (either of data from a single test using multiple analytical solutions or of data generated by repeated questionable slug tests) are not considered explicitly. For example, single-well aquifer tests were performed in 237 wells, yet a total of 261 water-level displacements were reported because replicate water-level displacements were measured in 18 wells (Stoller-Navarro Joint Venture, 2004, appendix C). These water-level displacements were then interpreted three times (Hvorslev, 1951; Cooper and others, 1967; and Butler, 1988), resulting in 783 reported estimates of hydraulic conductivity (Stoller-Navarro Joint Venture, 2004, appendix C).

Aquifer tests also have been reinterpreted multiple times because the wells were not defined uniquely. Previous databases and reports identified wells by borehole name, depth to top of open interval, and depth to bottom of open interval (Belcher and others, 2001; Stoller-Navarro Joint Venture, 2004, appendix C; John Hoaglund, Navarro, written commun., 2016). This approach introduces ambiguity without further specifications, because depths are referenced to land surface in the NWIS database (https://waterdata.usgs.gov/nwis) or to original field notes, where depths are referenced to rotary table heights (Wood, 2007). Rotary tables were used in well operations and typically ranged from 10 to $20 \mathrm{ft}$ above land surface. If the measuring point was not tracked consistently when defining a well, these ranges introduced enough difference for a well to appear as two unique wells if depths were tracked inconsistently.

Ambiguity in the reporting of well construction also resulted because tops and bottoms of open intervals in a constructed well were not defined consistently. Some investigators reported the contact between gravel pack and cement in the annulus as the top or bottom of an open interval. Other investigators reported the contact between well screen and blank casing as the top or bottom of an open interval. Reported depths differed by 10 to $100 \mathrm{ft}$ because of differences in defining tops and bottoms of open intervals. Tops and bottoms of open intervals typically were well-defined in the original analysis, but assumptions regarding whether the defining contact was in the annulus or casing were unreported in subsequent databases. 
The U.S. Geological Survey (USGS), in cooperation with the Department of Energy, completed a study to standardize single-well, aquifer-test results from Pahute Mesa and vicinity by uniquely identifying tested wells, reporting all replicated aquifer tests in each well, and identifying the best transmissivity estimate for each well. Each of the 360 wells tested was assigned a unique site identifier. Datasets, interpreted model, and results from 1,459 analyses are presented and evaluated. Each aquifer-test analysis was graded according to recognized quality-assurance criteria, which determined the best transmissivity estimate for each well.

Results from historical aquifer tests (Blankennagel and Weir, 1973) were integrated for 17 wellbores, resulting in depth-dependent hydraulic conductivity distributions from packer-isolated slug tests that agreed with integrated open-borehole pumping tests. Integration was needed because results from slug and pumping tests appeared to be inconsistent. These apparent inconsistencies primarily resulted from limitations of slug tests, which cannot quantify transmissivity in highly permeable intervals. These analyses generated consistent information about the depth and thickness of permeable rocks and had important implications for the transport timing and pathways of radionuclide materials beneath Pahute Mesa.

\section{Description of Study Area}

The study area focuses on Pahute Mesa, but includes wells near and downgradient of the mesa. The study area extends from Rainier Mesa in the east, to Timber and Yucca Mountains in the south and to Oasis Valley and Beatty in the west. Wells outside of Pahute Mesa were included as part of the study area to provide supplementary information about hydraulic properties between radionuclide source areas and potential downgradient receptors.

Pahute Mesa is approximately 130 miles northwest of Las Vegas, Nevada, and is in the northwestern part of the Nevada National Security Site (NNSS; fig. 1). The NNSS was the primary underground nuclear testing area in the United States from 1951 to 1992 (U.S. Department of Energy, 2015). Pahute Mesa was the underground testing site for large-yield (200 kiloton to more than 1 megaton) nuclear devices because the thick $(1,500-2,000 \mathrm{ft})$ unsaturated zone was sufficient to contain explosive force and test-generated radioactive byproducts. Eighty-two nuclear tests were detonated in Pahute Mesa, mostly near or below the deep water table.
Pahute Mesa is an elevated plateau of about 200 square miles and has altitudes ranging between 5,500 and more than 7,000 feet above mean sea level (Blankennagel and Weir, 1973). Pahute Mesa and Rainier Mesa, as well as Timber and Yucca Mountains, are a part of an extensive elevated volcanic terrain (Fenelon and others, 2010). Oasis Valley is a gently sloping valley bounded in the north by Pahute Mesa that terminates south of Beatty and has altitudes ranging between 4,000 and 3,200 feet above mean sea level (Reiner and others, 2002). Precipitation patterns for the study area are representative of the regional semi-arid to arid landscape. Most precipitation falls in winter and late summer months (Soulé, 2006). Annual precipitation averages 7.74 inches for Pahute Mesa (Soulé, 2006) and 6.33 inches for Oasis Valley (Reiner and others, 2002).

\section{Hydrogeology}

The study area is in the southwestern Nevada volcanic field, which consists of volcanic rocks from more than six calderas that episodically erupted between 15 and 9 million years ago (Sweetkind and others, 2001). Pahute Mesa was formed by relatively young volcanic materials deposited on the Silent Canyon caldera complex. Pahute Mesa and the surrounding volcanic field are composed of more than 1,000-ft thick sequences of welded and non-welded ash-flow and ash-fall tuffs that were subsequently faulted and fractured (Blankennagel and Weir, 1973; Fenelon and others, 2010). The study area also is underlain by minor volcanic deposits, including pyroclastics, tufa, and felsic-to-mafic lava flows that have been fractured. Volcanic rocks form aquifers in which fractures, faults, and joints form a hydraulically connected network that permits groundwater flow (Winograd and Thordarson, 1975; Sawyer and others, 1994).

Volcanic rocks in the study area have been classified as aquifers, composite units, or confining units. Rhyolitic lavas and densely welded ash-flow tuffs have well-connected fracture and joint networks that form the principal aquifers in the study area. Partially welded and nonwelded ash-flow and ash-fall tuffs typically form confining units because these rocks are susceptible to mineral alterations and zeolites, which reduce fracture permeability (Fenelon and others, 2016). Composite units are formations that include a combination of aquifers and confining units. Composite units are common in the study area because ash-flow tuffs tend to grade from nonwelded to partially or densely welded both laterally and vertically. As a result, a single ash flow can behave either as an aquifer or as a confining unit at different locations. 


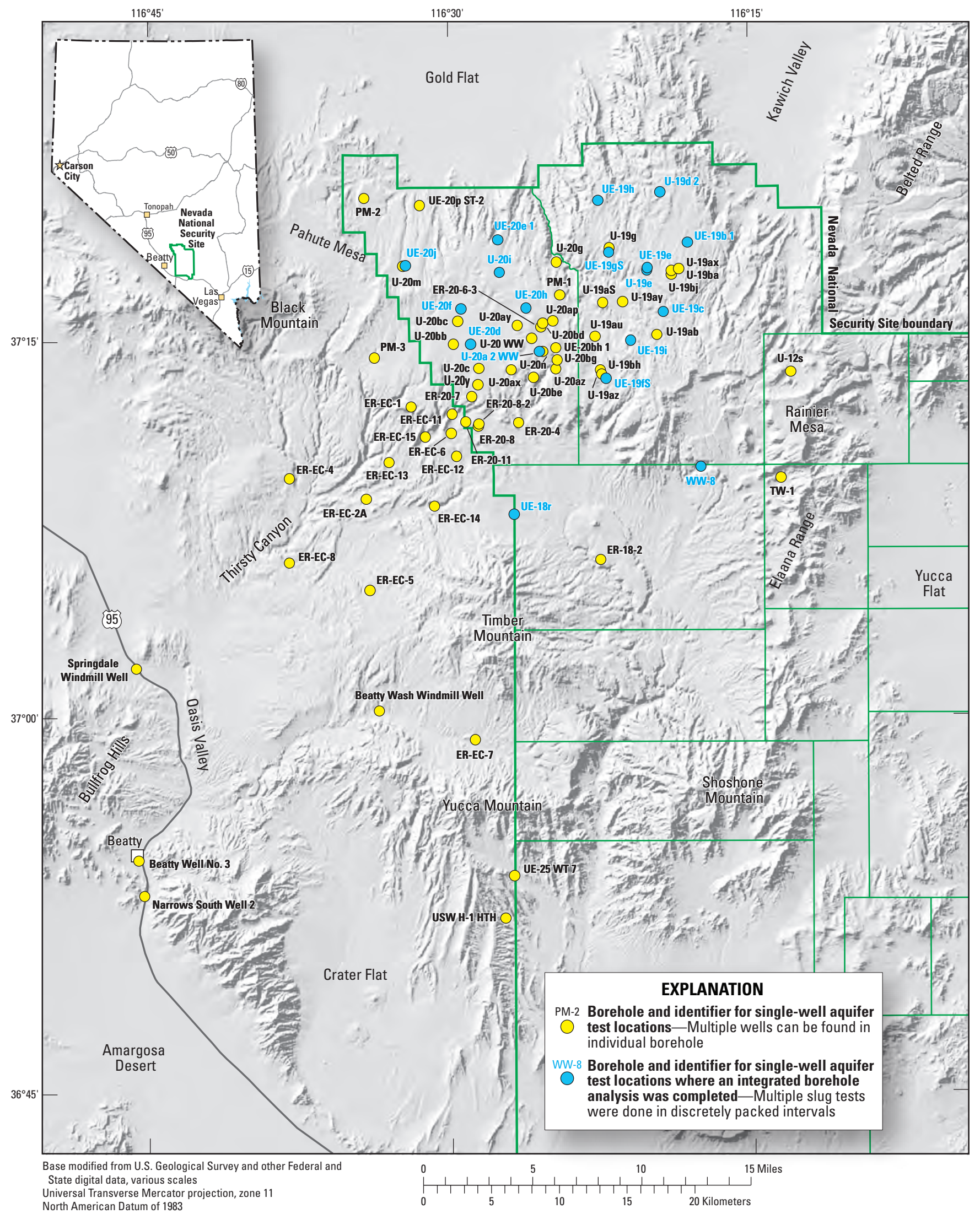

Figure 1. Geographic features and single-well aquifer test borehole locations on Pahute Mesa and vicinity, Nevada. 


\section{Well and Borehole Completions}

The terms "borehole" and "well" have specific definitions in this report. A "borehole" refers to the spatial (X, Y) location where a hole was drilled and is associated with the total depth of the drilled hole. A borehole may have one or more screened (or open) completions. A completion refers to a section of the borehole that has been isolated, either permanently or temporarily, from the rest of the borehole. An open completion indicates that there is no isolated section in the borehole. A "well" refers to a single completion in a borehole; therefore, a borehole may be one well or have more than one well. Examples of boreholes with multiple wells follow:

1. A borehole with one or more permanent main completions, where each main completion is a well.

2. A borehole with multiple main completions and one or more piezometers installed between the borehole annulus and main casing, where each main completion and piezometer is a well.

3. A borehole with one main completion, where discrete intervals of the main completion were temporarily isolated with packers, and each temporarily packed interval is a well.

Each aquifer test was associated with a well. A unique USGS site identification number and USGS site name was established in the NWIS database for each well (Frus and Halford, 2018). The terms well and site are interchangeable in this report. All well names are consistent with the NWIS database.

\section{Purpose and Scope}

The purpose of this report is to document aquifer tests and interpretations at Pahute Mesa and vicinity. Waterlevel and pumping data from 360 single-well aquifer tests completed between 1941 and 2014 were compiled. Singlewell aquifer tests included pumping tests, specific-capacity estimates, and slug tests. Many of the single-well aquifer tests had multiple interpretations because the tests were analyzed by different analytical models and multiple investigators or because the well locations were not uniquely identified. The 1,459 interpretations of the 360 single-well aquifer tests were compiled and assigned quality-assurance flags according to field-test conditions, analytical methods, and borehole effects. A best estimate of transmissivity was assigned for each well that was consistent with quality-assurance criteria. Aquifer-test data, analyses, interpretations, and quality-assurance flags with appropriate remarks are published in a "Hydraulic Properties Database" (Frus and Halford, 2018). Depthdependent hydraulic conductivity distributions were estimated in 17 boreholes by integrating results from pumping tests and depth-dependent slug tests. Data, analyses, and interpretations of depth-dependent hydraulic conductivity distributions are available in an "Integrated Borehole Analysis Database" (Frus and Halford, 2018).

\section{Single-Well Aquifer Tests}

Single-well aquifer tests consist of monitoring water-level changes in a well before, during, and after a known volume of water is either injected or removed from a formation open to the well. Single-well aquifer tests are described in this report, including pumping and slug tests. Water is typically removed from the well (pumped) at a constant rate during pumping tests. A volume of water, or "slug," is injected or removed instantaneously during slug tests. Pumping and adding or removing a "slug" of water to a well are collectively referred to as applying "stresses," because the removal or injection of water in the well perturbs the surrounding aquifer system and causes a hydraulic response in the form of a water-level decline or rise. A water-level decline in response to removing water (pumping) from a well is referred to as "drawdown." After pumping is stopped, the resulting water-level rise is referred to as "recovery." When water is instantaneously injected (slug) into a well, the water level rises, but then returns to the pre-stressed conditions; this is also referred to as "recovery." Water levels are measured before, during, and after an aquifer test to differentiate drawdown and recovery from water-level changes caused by environmental factors, such as barometric pressure (Stallman, 1971).

Hydraulic properties of the formation intersected by a well can be estimated from aquifer tests by a curve-matching approach that fits an analytical solution to drawdown or recovery data. Numerous analytical solutions exist and are derived from the application of simplifying assumptions to Darcy's law, such as radial flow toward a pumping well in a homogeneous, isotropic aquifer. Hydraulic properties, such as transmissivity and storativity, are fitting parameters used to match the analytical solution to plots of drawdown against time. Type-curve methods, such as Theis (1935), match an analytical solution to log-log plots of drawdown against time, whereas straight-line methods, such as Cooper and Jacob (1946), match an analytical solution to semi-log plots of drawdown against time. 
Transmissivity estimates from pumping tests are more representative of aquifer properties than estimates from slug tests because greater volumes of water are displaced, causing greater volumes of aquifer to be investigated. When large volumes of water are removed from the groundwater system, drawdowns in the pumping well reflect the "bulk" of hydraulic properties of the aquifer near and far from the pumping well. Compiled data from single- and multiple-well aquifer tests in the study area showed that pumped volumes ranged between 3,000 and 14,000,000 gallons from individual tests. Displaced volumes from slug tests in wells in the study area, other than emplacement holes, ranged between 1 and 870 gallons and averaged 440 gallons. The average volume of water removed during pumping tests was about 4,000 times the average volume of water displaced during slug tests. Empirical approximations, based on volume pumped, estimated radial distance from the pumping wells typically exceeded $1,000 \mathrm{ft}$ during the pumping tests, whereas the investigated radial distance was estimated at less than $50 \mathrm{ft}$ from the wellbore during slug tests.

Reporting was limited to estimates of transmissivity because other aquifer properties cannot be estimated reliably from single-well aquifer tests (Halford and others, 2006). Using straight-line methods, transmissivities can be related to slopes of water-level changes on semi-log plots. Aquifer responses resulting in more complex patterns than this single straight-line slope, such as dual porosity or leakyconfined conditions, cannot be observed during a single-well test. These responses can be explained with more complex analytical solutions than the Cooper-Jacob Method (Cooper and Jacob, 1946), but additional hydraulic properties, such as leaky aquitard saturated thickness and vertical hydraulic conductivity, cannot be estimated uniquely by single-well aquifer tests (Halford and others, 2006). Three-dimensional groundwater-flow models that simulate unconfined (Neuman, 1974) or dual-porosity (Moench, 1984) conditions are more appropriate for interpreting multiple-well aquifer tests because sufficient data exist to estimate additional hydraulic properties (Fetter, 2001).

Transmissivity was reported rather than hydraulic conductivity because the contributing thickness of the aquifer usually is unknown. The contributing thickness generally is the same as the total aquifer thickness for pumping tests where transmissivity exceeds 1,000 square feet per day $\left(\mathrm{ft}^{2} / \mathrm{d}\right)$, regardless of partial penetration and vertical anisotropy (Halford and others, 2006). Aquifer thicknesses beneath Pahute Mesa generally cannot be determined from geologic cross sections or hydrostratigraphic framework models because hydraulic conductivities did not correlate well to mapped aquifer and confining units (Mirus and others, 2016; Garcia and others, 2017). Correlation was minimal because hydraulic conductivities ranged over several orders of magnitude within hydrostratigraphic units, and ranges greatly overlapped between aquifer and confining units (Belcher and others, 2002; Garcia and others, 2017).
Aquifer-test results are most likely to be misinterpreted in groundwater-flow and transport models if transmissivities are independently reduced to hydraulic conductivities. Reducing transmissivity to hydraulic conductivity requires an assumed thickness, which frequently defaults to lengths of production-well open intervals in the absence of other data. This introduces unnecessary errors where assumed thicknesses from aquifer tests and thicknesses in groundwater-flow models differ (Halford and others, 2006). For example, results from pumping well $E R-E C$ - 1 were reported as hydraulic conductivities of 19.83 and 56.84 feet per day (ft/d) for assumed contributing thicknesses of 289.5 and $101 \mathrm{ft}$, respectively (IT Corporation, 2002). Different contributing thicknesses add unnecessary uncertainty, because transmissivity was $5,700 \mathrm{ft}^{2} / \mathrm{d}$ in both interpretations. An aquifer thickness of 1,600 ft had been assumed previously around well $E R-E C-1$ in a groundwater flow model (Belcher, 2004). Assigning a hydraulic conductivity of $57 \mathrm{ft} / \mathrm{d}$ resulted in a simulated transmissivity of $90,000 \mathrm{ft}^{2} / \mathrm{d}$, which overestimated aquifer-test results by more than an order of magnitude.

Similar interpretative problems can result if slug-test results are reduced to average hydraulic conductivities when rock matrix and fractures were simulated discretely in the length of open interval. Contributing thickness and length of open interval generally are interchangeable for slug tests because small volumes are displaced relative to pumping tests. Problems arise in interpreting slug-test results from wells in fractured rock because intervals considerably smaller than the tested interval can be most transmissive. For example, transmissivity was more than $300 \mathrm{ft}^{2} / \mathrm{d}$ in well $U E-18 \mathrm{r}(2193-$ $2393 \mathrm{ft}$ ), which had a 200-ft open interval, and hydraulic conductivity averaged $1.6 \mathrm{ft} / \mathrm{d}$. Most of the transmissivity was in a 10-ft interval from 2,350 to 2,360 ft (Blankennagel and Weir, 1973). Hydraulic conductivity of the fracture would be $30 \mathrm{ft} / \mathrm{d}$, and that of the rock matrix would be less than $0.01 \mathrm{ft} / \mathrm{d}$, if fractures were simulated explicitly. The average hydraulic conductivity of $1.6 \mathrm{ft} / \mathrm{d}$ was not representative of the fracture or the rock matrix.

\section{Pumping Tests}

Pumping tests at Pahute Mesa were designed as constantrate tests and interpreted principally as such. More than 90 percent of the 42 pumping tests were interpretable as constant-rate tests, which included drawdown after pumping started and recovery after pumping stopped. Aquifer tests in wells ER-EC-11 main, ER-EC-14 deep, and ER-EC-15 intermediate were analyzed with alternative approaches because confounding factors affected water levels during drawdown and recovery. Water levels rose in wells ER-EC-11 main and ER-EC-14 deep during pumping because of thermal expansion, which caused ambiguous results. Well ER-EC-15 intermediate produced poorly and was pumped cyclically at average and maximum rates of 4 and 12 gallons per minute (gpm), respectively. 
Constant-rate tests frequently are analyzed by plotting drawdown and recovery data on semi-log plots and are interpreted using straight lines (Halford and others, 2006). In this report, drawdown data were interpreted by the CooperJacob (1946) method, and recovery data were interpreted by the Jacob (1963) method. Recovery data were plotted on a transformed $\mathrm{X}$-axis of time-since-pumping-started divided by time-since-pumping-stopped, $\Delta \mathrm{t}_{\text {START }} / \Delta \mathrm{t}_{\text {STOP }}$ (Jacob, 1963). Increased time plots to the left on the axis for transformed recovery data, where $\Delta \mathrm{t}_{\text {START }} / \Delta \mathrm{t}_{\text {STOP }}$ has large values when recovery starts that theoretically diminish to 1 after infinite recovery (fig. 2). Transmissivity is inversely proportional to the slope of water-level change both in the Cooper-Jacob (1946) and in the Jacob (1963) methods. Slopes of drawdown and recovery data theoretically should be identical, because transmissivity of the aquifer defines the slope.

The Cooper-Jacob (1946) and Jacob (1963) methods were combined so that drawdown and recovery could be interpreted simultaneously (fig. 2). Translated recovery data were shifted left on the $\mathrm{X}$-axis of $\Delta \mathrm{t}_{\text {START }} / \Delta \mathrm{t}_{\text {STOP }}$ so that the first recovery observation coincided with the last drawdown observation. Translation does not affect the slope, so drawdown and recovery data can be interpreted simultaneously. If the drawdown and recovery data did not exactly match, a mechanistic approach was used to provide a best fit of semi-log slopes to relevant data (Halford and others, 2006). Drawdown and recovery data were both analyzed for 26 of the 42 constant-rate tests. Data were limited to just drawdown for 14 wells and just recovery for 2 wells.

A standardized Microsoft Excel ${ }^{\circledR}$ workbook was developed to simultaneously analyze drawdown and recovery data from constant-rate pumping tests (fig. 3). General data quality was evaluated by plotting time series of depth-towater and discharge. Water levels were assessed visually to determine whether confounding factors, such as wellbore storage, thermal expansion, or stresses other than pumping, affected measurements. Water levels affected by confounding factors were not analyzed and were excluded from the semilog plot. Analyzable drawdown and translated recovery data were plotted on a single semi-log plot. Parallel lines were drawn from the leftmost measurement in each data segment, where slope was adjusted manually to match the analytical model to the data. Best fit was determined visually so that confounding effects of variable pumping rates, thermal expansion, environmental fluctuations, and unknown drift since pumping started could be discounted.
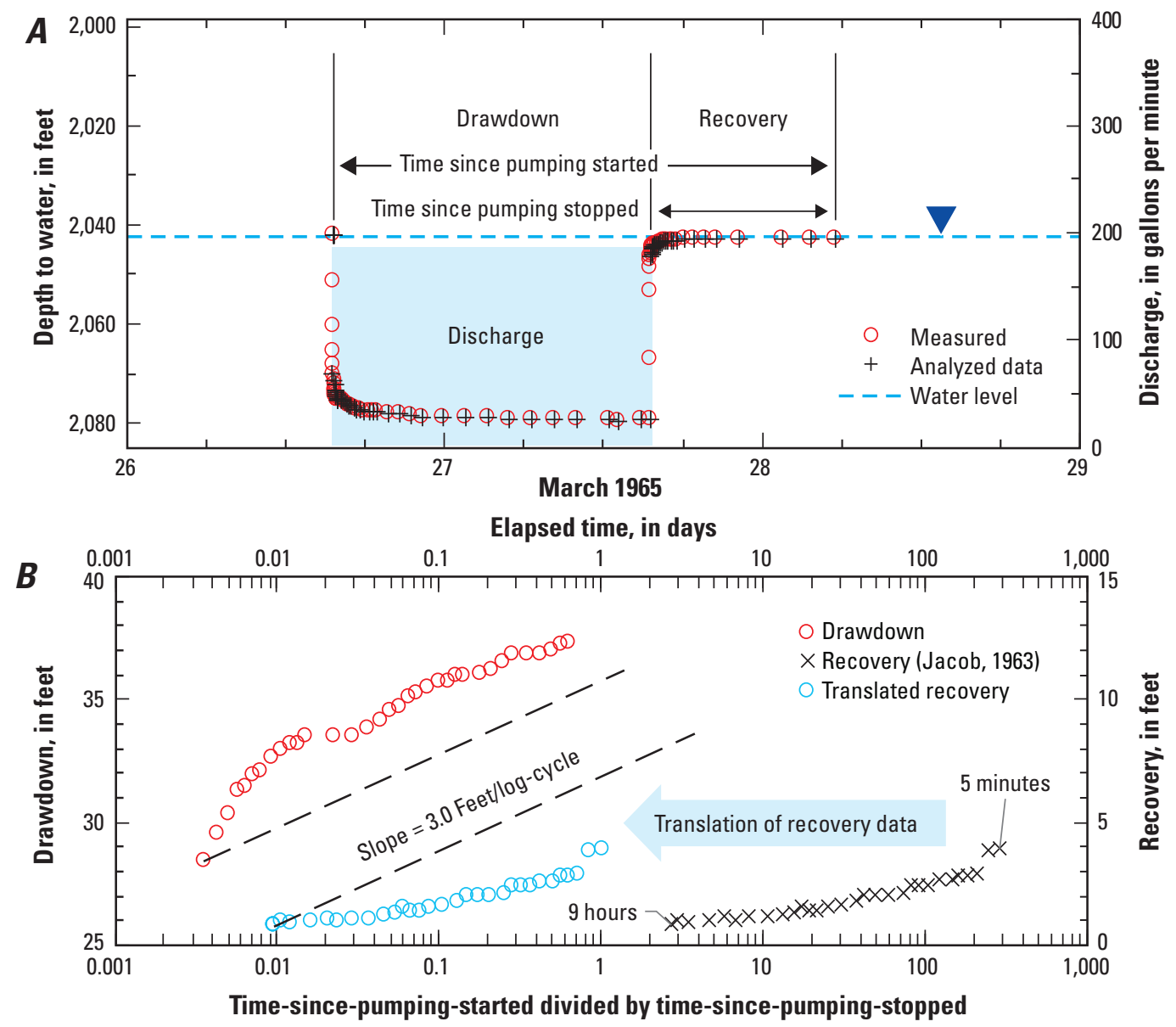

Figure 2. Examples of pumping test results in well UE-19gs (2650-4508 ft) from March 1965. $A$, Cartesian plot of changes in depth to water relative to drawdown and recovery; $B$, Semi-log plot of translated recovery data combined interpretation of drawdown and recovery. 


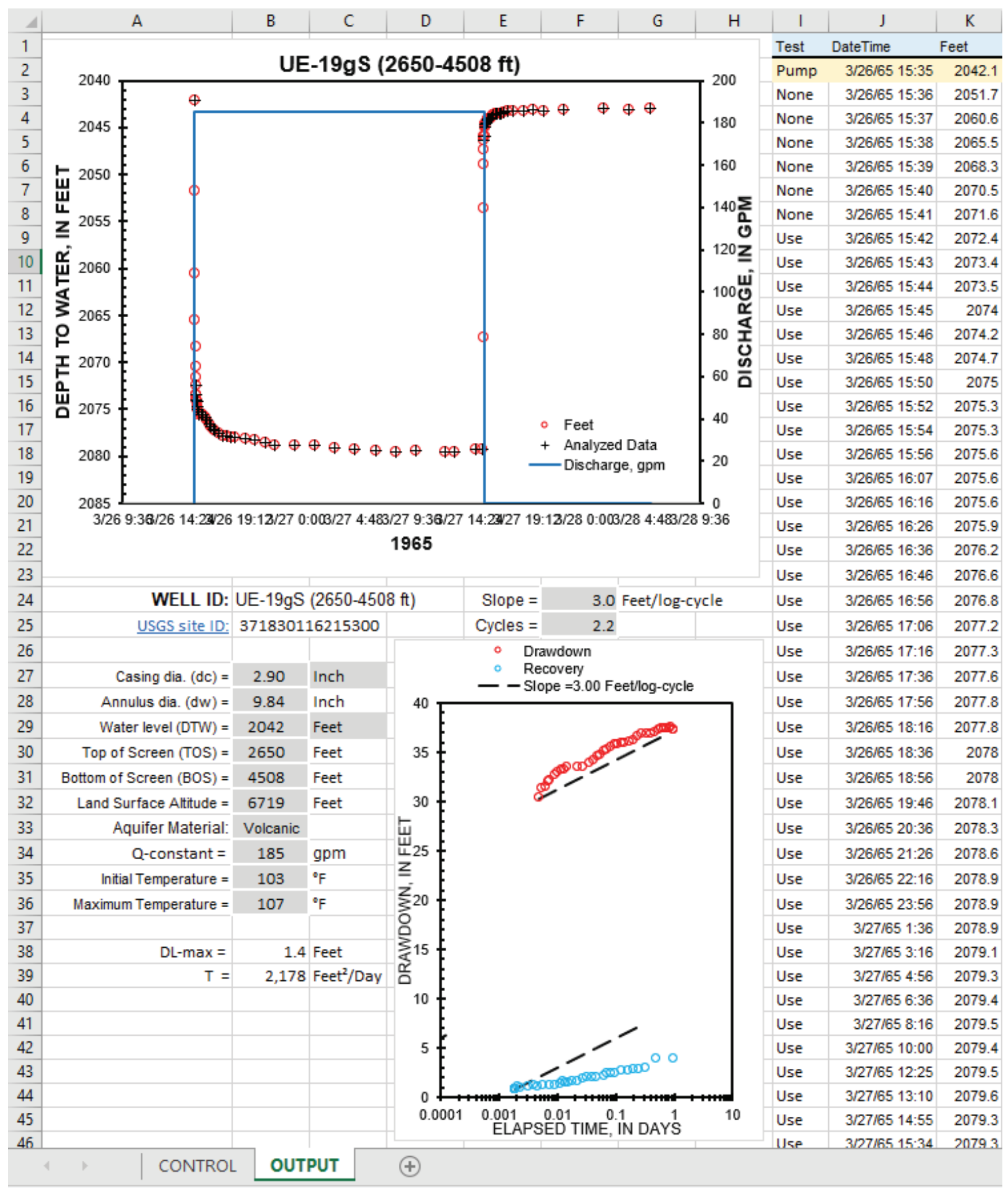

Figure 3. Example of a standardized Microsoft Exce ${ }^{\circledR}$ workbook for simultaneously interpreting drawdown and recovery from constant-rate aquifer tests. 
Effects of thermal expansion were observed as rising water levels during pumping. In a typical isothermal pumping scenario, water levels decline in the pumping well because the hydraulic head is lowered in the aquifer around the well. In a thermal expansion scenario, pumping the well lowers the hydraulic head in the aquifer, but water-level changes in the well reflect the net effect of water-level decline from lowering aquifer head and of water-level rise from warmer formation water entering the well and heating the water column in the wellbore. Water-level rises in the well if the rate of rise from thermal expansion exceeds the rate of decline from aquifer drawdown.

Correcting measured water levels for thermal expansion requires time series of water temperature during pumping and an estimated length of the water column between the free-water surface and the contributing interval to the well. The contributing interval is defined as the discrete interval within a well completion that contributes most of the flow to the well. On the NNSS, contributing intervals usually are a few discrete fractures for any given well. In the absence of flow logs, knowledge of the contributing intervals (flowing fractures) within the well completion was largely absent. Arbitrarily assuming that the contributing interval is the top or bottom of the well completion can cause computed lengths of the water column to differ by more than $1,000 \mathrm{ft}$, because study-area wells are deep and open intervals are long. Watercolumn length increases as pumped water increases the average temperature. Water expands at rates of 0.1 to $0.3 \mathrm{ft} /$ Fahrenheit $\left({ }^{\circ} \mathrm{F}\right) / 1,000 \mathrm{ft}$ between temperatures of 60 and $150^{\circ} \mathrm{F}$, respectively.

Thermal expansion affected aquifer-test results at Pahute Mesa because there could be more than 1,000 ft of water between the free-water surface and contributing interval, water-table temperatures ranged from 80 to $90^{\circ} \mathrm{F}$, and geothermal gradients ranged from 8 to $17^{\circ} \mathrm{F} / 1,000 \mathrm{ft}$ beneath Pahute Mesa (Reiner, 2007). For example, heating a 2,000-ft column of water from 95 and $105^{\circ} \mathrm{F}$ would raise water levels $4.5 \mathrm{ft}$. Thermal expansion was an important confounding effect in 5 of 42 pumping tests.

Effects of thermal expansion on transmissivity estimates were minimized by interpreting drawdown and recovery data when temperatures were least likely to change. Drawdowns predominantly were affected by pumping several hours after pumping started because temperature of the water column was relatively uniform prior to pumping. Straight lines were primarily fitted to late-time pumping data, and early-time drawdown and recovery data were secondary priorities. For example, temperature of discharge water ranged from 86 to $114{ }^{\circ} \mathrm{F}$ at well $U-19 d 2$ when the well was pumped. A maximum water-level rise of $13 \mathrm{ft}$ from thermal expansion was estimated by subtracting measured water-level changes from a Theis estimate of head change resulting from pumping (fig. 4).

Pumping tests were interpreted previously using analytical models that were not supported by information in a single-well aquifer test (Halford and others, 2006). Solving for wells of finite diameter simulated wellbore storage and permitted estimation of well skin (Papadopulos and Cooper, 1967; Dougherty and Babu, 1984; Moench, 1985). Aquifer characterization was not improved because the well skin primarily characterizes well construction. Estimated well skin also was non-unique, because well skin and storage coefficient are correlated if estimated from a single-well aquifer test (Halford and others, 2006). More complex models that simulate dual porosity (Moench, 1984; Barker, 1988), discrete fracture flow (Gringarten and others, 1974), leaky confining units (Hantush and Jacob, 1955; Moench, 1985), or unconfined conditions (Neuman, 1974) might have been appropriate conceptually, but did not improve aquifer characterization. Transmissivity estimates generally were unaffected by added complexity, but all other aquifer parameters were not estimable (Halford and others, 2006). 

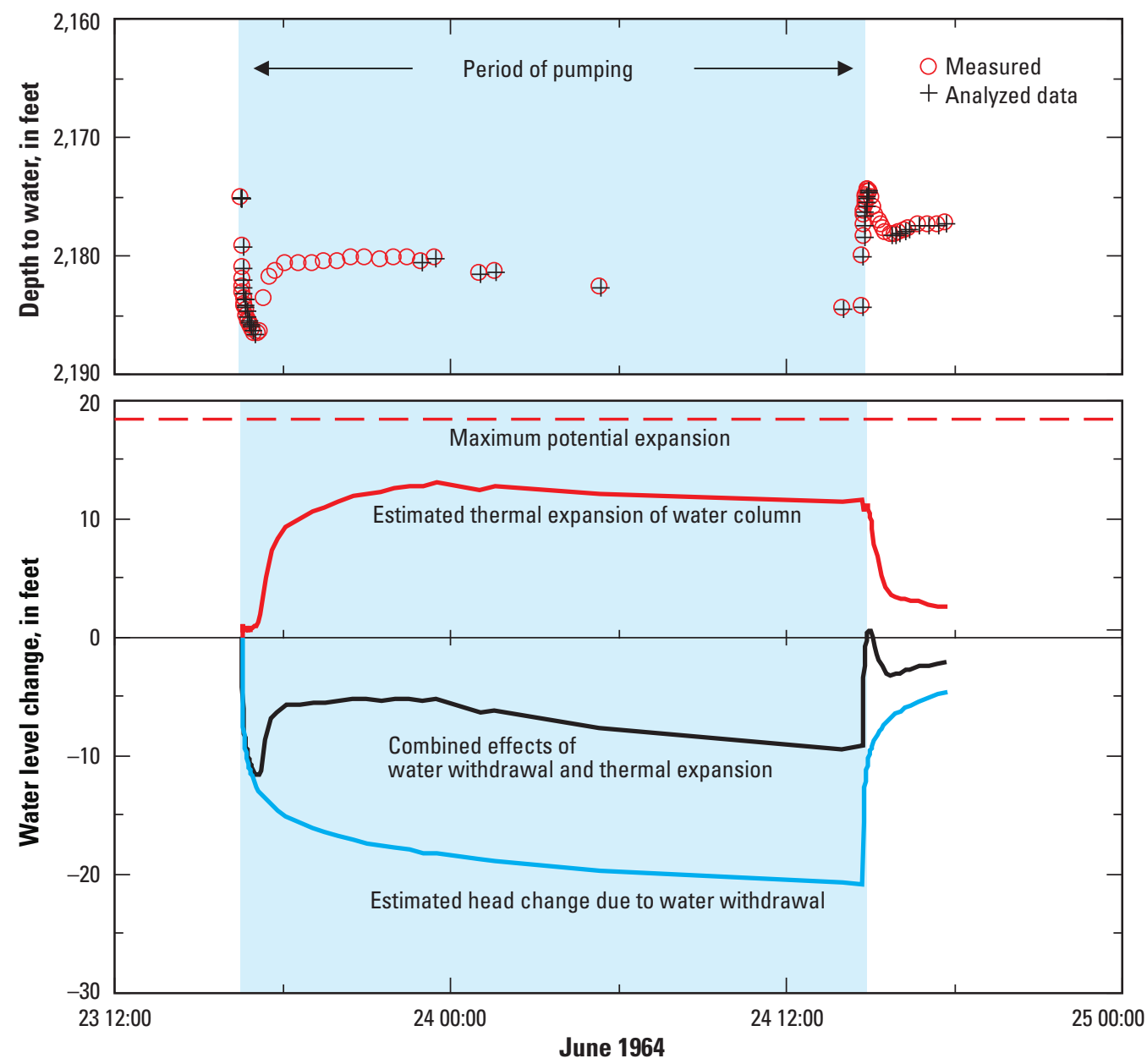

Figure 4. Estimated effects of water withdrawal and thermal expansion on measured water levels in well U-19d2, for which measured temperatures of discharge ranged between 86 and 114 degrees Fahrenheit, June 1964. 


\section{Specific Capacity}

Hydraulic data were limited to specific capacity for wells Beatty Wash Windmill Well, Beatty Well No. 3, Narrows South Well 2, Springdale Windmill Well, and ER-EC-14 deep. Specific capacity is discharge divided by drawdown, where it is assumed that any change over time is minor. Specific capacity ranged between 1 and 13 gallons per minute per foot $(\mathrm{gal} / \mathrm{min} / \mathrm{ft})$ in the five wells. A 10-day constant-rate test was done in well ER-EC-14 deep, but the data could not be interpreted as a single-well aquifer test because the water rise from thermal expansion during pumping obscured drawdown (Garcia and others, 2017).

Transmissivity was empirically estimated from specific capacity by a local power-law relation that was developed previously in California and Nevada (Thomasson and others, 1960; Yager and others, 2012). Transmissivity and specific capacity estimates from 39 constant-rate aquifer tests defined the relation (fig. 5), such that transmissivity ( $\mathrm{ft}^{2} / \mathrm{d}$ ) equaled 380 times specific capacity (gal $/ \mathrm{min} / \mathrm{ft})$. The local relation for Pahute Mesa functionally differed little from other empirical relations. Transmissivity estimates from specific capacities ranged between 300 and 5,000 ft²/d (fig. 5).

\section{Slug Tests}

Slug tests beneath Pahute Mesa were primarily intended to locate low-permeability rocks suitable for the testing of nuclear devices (Blankennagel, 1967; Blankennagel and Weir, 1973). More than 90 percent of the 309 historical slug tests were done using straddle packers that isolated 38- to 198 -ft-thick intervals within a borehole. Alternative approaches were used for 24 wells in low-permeability rocks, where recovery from drilling could be interpreted as a slug test (Halford and others, 2005). Recovery periods ranged from 20 to 9,000 days during these opportunistic slug tests, which were much greater than the recovery periods of less than an hour during straddle-packer slug tests. Additionally, well ER-EC-12 intermediate was pumped dry within 15 minutes of pumping at a rate of $10 \mathrm{gal} / \mathrm{min}$. Water levels in well $E R-E C-12$

intermediate were measured for 7 days of recovery, and these data were also evaluated as a slug test.

For the straddle-packer slug tests, target intervals were isolated from the rest of the borehole by straddle packers. A 3-inch inner-diameter tube typically connected the top straddle packer to land surface. For each slug test, water was either quickly injected into or removed (swabbed) from the tube to approximate either an instantaneous injection or swabbing of the isolated interval, respectively. At the surface, a wireline for measuring changes in water levels was then moved into position and lowered into the tube. The wireline measures water-level declines at 30 second, or longer, intervals. The straddle-packer slug-testing method is described fully in Blankennagel (1967).

Measurements were limited during the straddle-packer slug tests because water levels could not be measured more frequently than every 30 seconds with wirelines (Blankennagel, 1967). Wireline measurements were inadequate to measure rapid water-level changes (fig. 6) where transmissivity of an isolated interval exceeded $200 \mathrm{ft}^{2} / \mathrm{d}$ (fig. 6). Transmissivity estimates from these tests are reported as a minimum for the tested interval.

Slug tests were analyzed using a standardized Microsoft Excel workbook that displays a time series of depth to water and a semi-log plot of normalized displacement (fig. 7). Depth-to-water data were plotted on a Cartesian plot to distinguish the period of water-level recovery from water levels that reflect static or quasi-static conditions. Static water levels were estimated from neighboring wells, measurements in the well after the slug test, or interpreted between injection and swabbing recoveries (Blankennagel and Weir, 1973; Wood, 2007; Elliott and Fenelon, 2010). Water levels representative of static conditions were excluded from the slug displacement analysis. Transmissivity was estimated using the Bouwer and Rice (1976) solution by visually fitting a straight line to normalized displacements on a semi-log plot (fig. 7).

Analytical models other than Bouwer and Rice (1976) were not considered because differences between other analytical solutions, such as Hvorslev (1951), were minor, and multiple parameter solutions were not appropriate. Underdamped responses were not observed in any of the slug tests, so oscillatory solutions such as Hyder and others (1994) or Butler and Garnett (2000) were not considered. Multiple parameter solutions such as Cooper, Bredehoeft, and Papadopoulos (1967) conceptually have merit, but were disregarded because transmissivity and storage coefficient cannot be estimated independently from a slug test. 


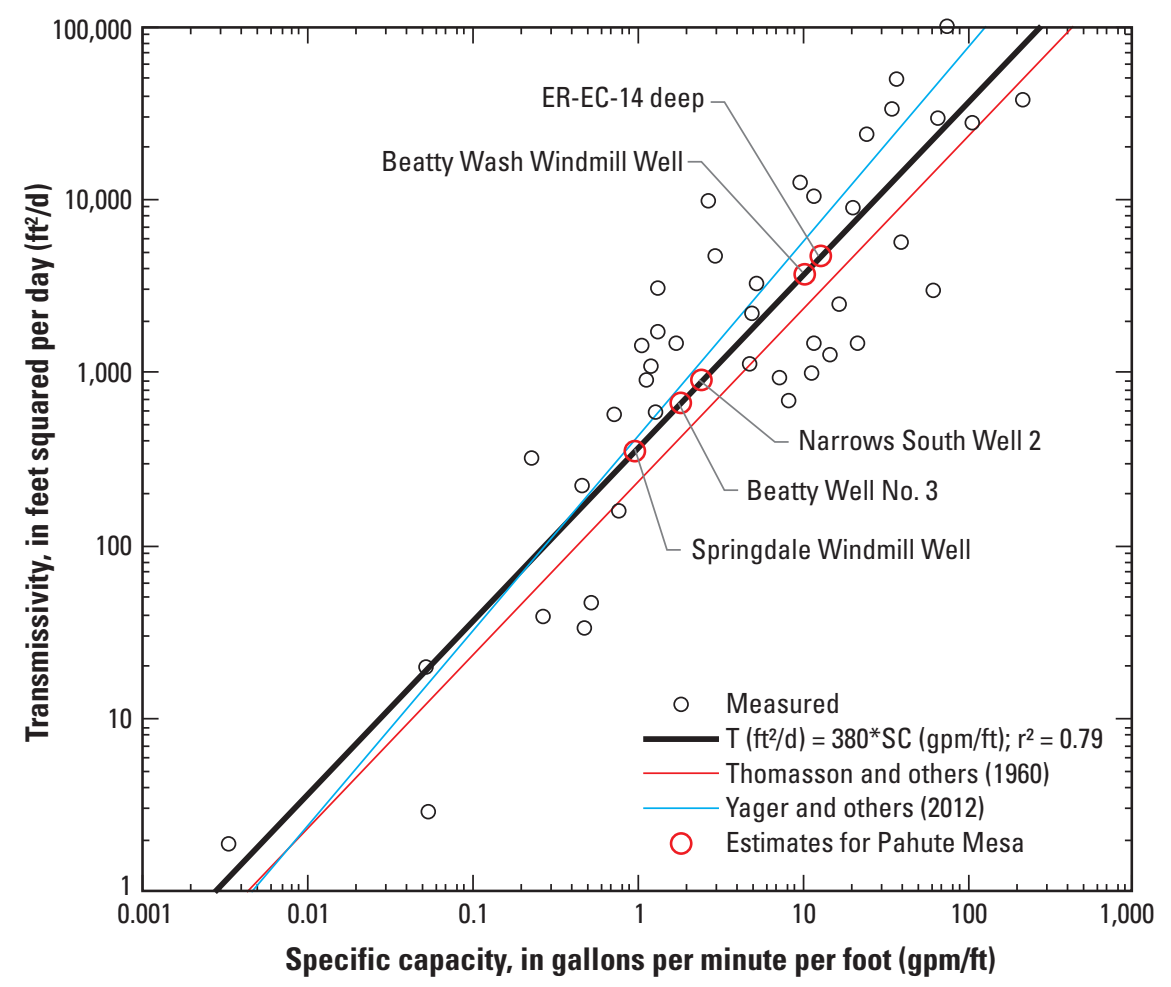

Figure 5. Relation between specific capacity and transmissivity from aquifer-test results at Pahute Mesa and vicinity. 


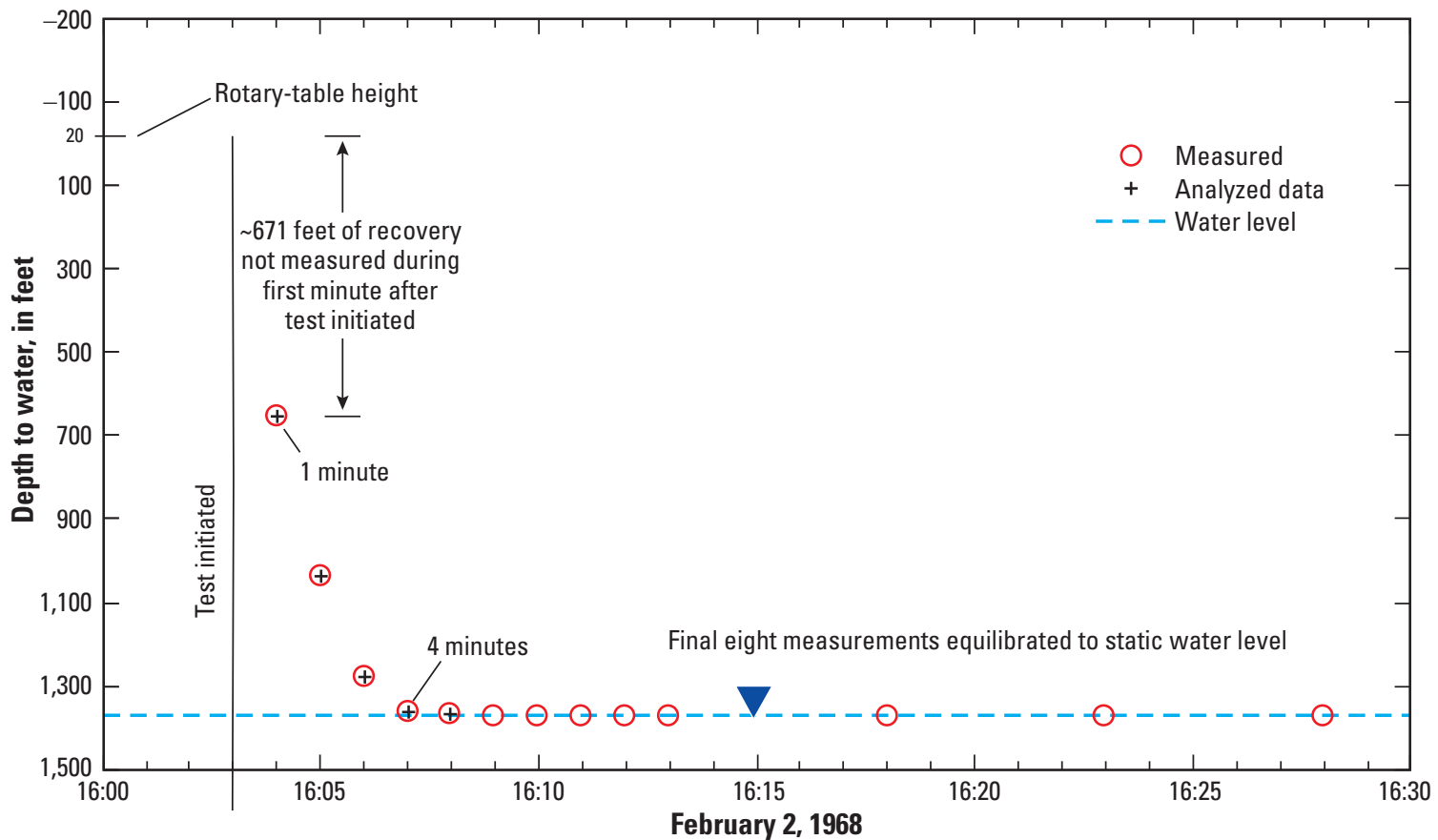

Figure 6. Changes to water level over time in well UE-18r (3442-3642 ft). Example of equipment limitations for recording recovery from injection tests, February 2, 1968. 


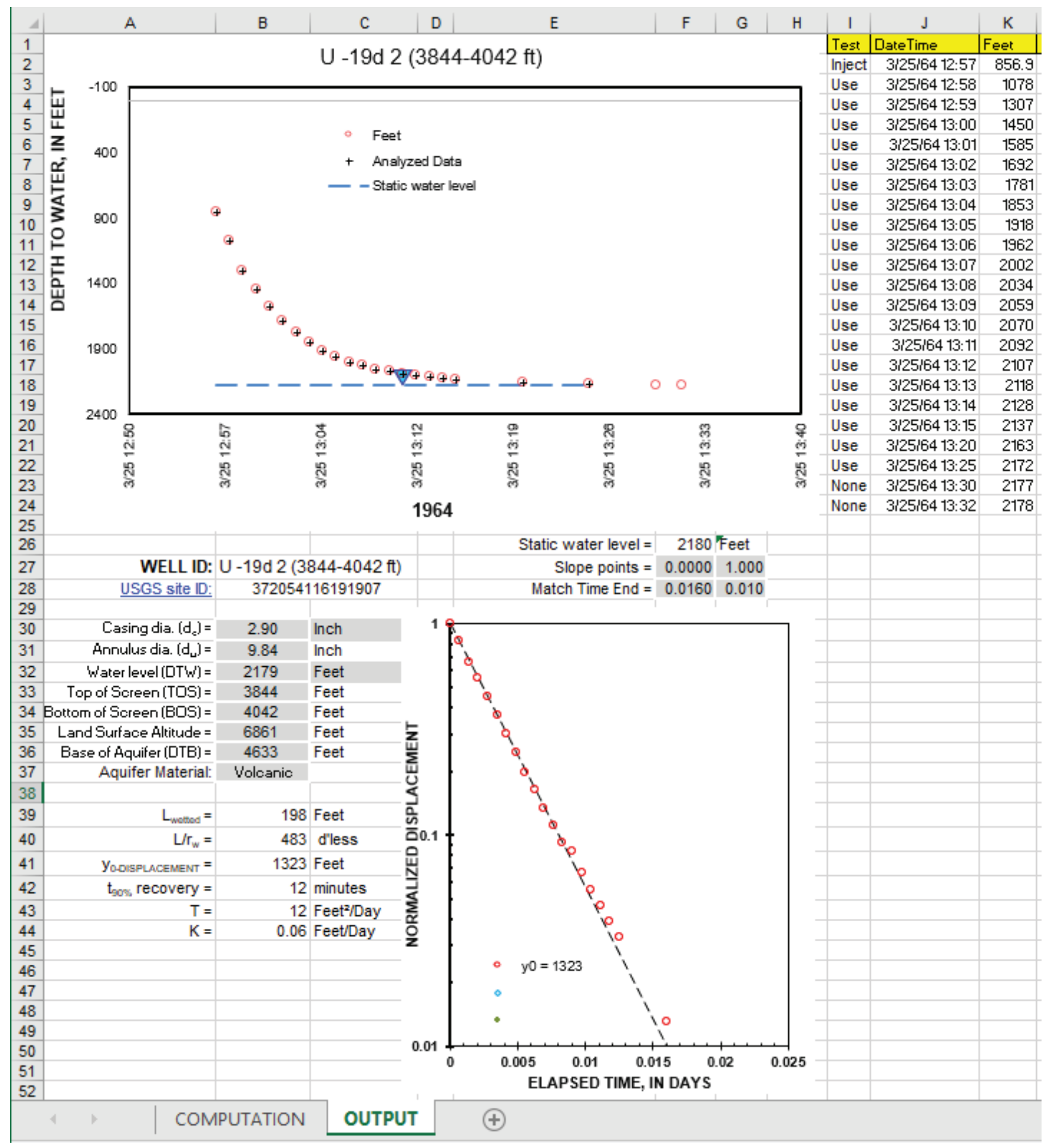

Figure 7. Example of a standardized Microsoft Exce ${ }^{\circledR}$ workbook for interpreting recovery from slug tests. 


\section{Data Compilation, Analysis, and Synthesis}

One or more hydraulic-property estimates were reported for each study-area well. The apparent number of investigated sites and independent single-well aquifer tests was inflated greatly. The majority of wells had multiple hydraulic-property estimates because of the following:

1. One or more investigators interpreted the same aquifertest dataset using one or more analytical models.

2. Repeated aquifer tests, from the same well, were interpreted independently from each other.

3. Different periods of analysis (drawdown or recovery) were selected independently and interpreted using one or more analytical models.

4. Well locations were not defined uniquely by all investigators.

5. Assumed aquifer properties, such as wetted thickness area, were assigned different values and then re-analyzed using one or more analytical models.

Because of these factors, 1,459 single-well aquifer tests had been analyzed for 360 uniquely identified wells. For each study-area well, aquifer-test data and analyses were compiled and quality assured to identify and report only the best transmissivity estimate for each well. A "Hydraulic Properties Database" (Frus and Halford, 2018) was created to catalog results from all study-area wells.

\section{Data Compilation}

Aquifer-test data and analyses were compiled from digital databases and published reports. Historical aquifer-test data were available after transcription from paper field notes to digital databases (Wood, 2007). Associated water-level measurements, site characteristics, and well-construction information remain readily available from the NWIS database (https://waterdata.usgs.gov/nwis). Hydraulic property estimates were compiled from Stoller-Navarro Joint Venture (2004, appendix C); Belcher and others (2001); Blankennagel and Weir (1973); Kilroy and Savard (1996); Garcia and others (2017); Mirus and others (2016); and the IT Corporation (1998).

\section{Aquifer-Test Evaluation}

Aquifer-test data were quality assured and resulting analyses were critically evaluated using a data-quality (DQF) protocol. The DQF protocol grades each pumping-test analysis (table 1), slug-test analysis (table 2), and resulting transmissivity estimate from A to F (excluding E) for each single-well aquifer test. These data-quality flags were used to grade transmissivity estimates when multiple aquifer-test analyses had been done for each well. The transmissivity estimated from the aquifer-test analysis having the highest DQF was considered the "best" estimate. The 1,459 aquifertest analyses were evaluated using the DQF protocol to provide one "best" transmissivity estimate for each of the 360 study-area wells.

In general, data-quality flag categories were based on the data-quality criteria, as follows: A, high-quality pumping and recovery data and analysis; B, medium-to-high-quality data and analysis; C, medium-to-low-quality data or analysis with greater than 50-percent recovery; $\mathrm{D}$, low-quality data or analysis with less than 50-percent recovery; and $\mathrm{F}$, data or analysis that is invalid and should not be considered.

Quality-assurance criteria evaluated the following: aquifer-test type, water-level data (Elliott and Fenelon, 2010; U.S. Geological Survey, 2018a), discharge data, confounding factors observed in the data or in the associated field notes (Wood, 2007), and analytical solution used. Transmissivity estimates from pumping tests were graded highest, compared to slug tests, because larger volumes of aquifer were investigated (Halford and others, 2006). Water-level data were qualified by consistency of response to aquifer-test stress and measurement frequency. Field notes identified variable pumping rates, leakage across packers, or presence of "suds" that reduced data quality. Appropriateness of analytical solution considered agreement between conceptual model of analytical solution and field conditions.

\section{Pumping Tests}

Pumping tests were graded with an "A" if pumping rates were constant, drawdown was unaffected by confounding factors, and the analytical solution selected agreed with observed drawdown. An example of an " $A$ " grade is the constant-rate pumping test done in well ER-18-2 from March 13, 2000, to March 21, 2000. During the constant-rate test, well $E R-18-2$ was pumped at a rate of about $10 \mathrm{gal} / \mathrm{min}$ for 7 days. Maximum drawdown in the well was about $190 \mathrm{ft}$, and full recovery was within 14 days. Field notes indicated no confounding factors ("good" conditions), and data indicated no observable fluctuations during drawdown. Observed drawdown and recovery were explained well by the combined Cooper-Jacob (1946) and Jacob (1963) method. Estimated transmissivity of volcanic rocks open to well $E R-18-2$ was $3 \mathrm{ft}^{2} /$ day. Uncertainty in estimated transmissivity was within a factor of 1.3 , because pumping rates were steady, and drawdown and recovery data were minimally affected by environmental conditions. 
Table 1. Data and analytical solution quality criteria for pumping tests.

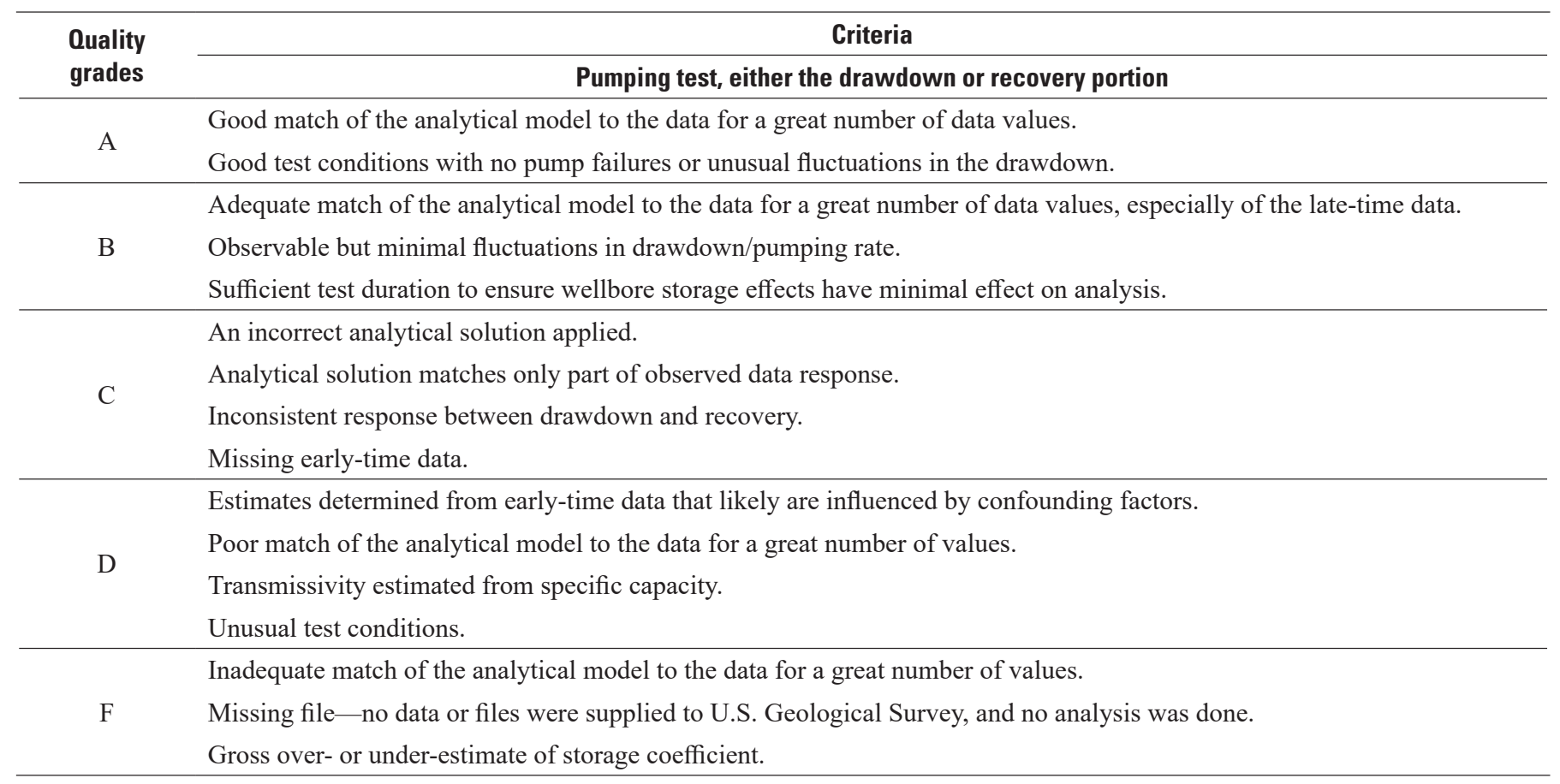

Table 2. Data and analytical solution quality criteria for slug tests.

\begin{tabular}{|c|c|}
\hline \multirow{2}{*}{$\begin{array}{l}\text { Quality } \\
\text { grades }\end{array}$} & Criteria \\
\hline & Slug test, either falling or rising water level \\
\hline A & Not applicable \\
\hline \multirow[t]{2}{*}{$\mathrm{B}$} & Sufficient test duration to obtain at least 70-percent recovery to static water level. \\
\hline & Repeated tests have similar results. \\
\hline \multirow{2}{*}{$\mathrm{C}$} & Short test duration that results in 50-70-percent recovery to static water level. \\
\hline & Non-ideal test conditions with limited or noisy early-time data. ${ }^{1}$ \\
\hline \multirow{2}{*}{$\mathrm{D}$} & An incorrect analytical solution applied. \\
\hline & Estimates determined from early-time data that likely are influenced by confounding factors. \\
\hline \multirow{4}{*}{$\mathrm{F}$} & Field notes indicate leakage, blockage, or "blow-out" of packer. \\
\hline & Inadequate match of the analytical model to the data for a great number of values. \\
\hline & Missing file — no data or files were supplied to U.S. Geological Survey, and no analysis was done. \\
\hline & Gross over- or under-estimate of storage coefficient. \\
\hline
\end{tabular}

\footnotetext{
${ }^{1}$ Test duration can include multiple years.
} 
Transmissivity estimates from pumping tests were graded less than " $\mathrm{A}$ " if data were degraded or selected analytical models were not supported by data from a single-well aquifer test. Examples of data degradation include insufficient drawdown or recovery data, variable pumping rates, thermal expansion during testing (fig. 4), and packer leakage or failure. Interpreting drawdown estimates using an inappropriate analytical model also was penalized, reducing the overall grade of a transmissivity estimate. An example is well UE-18r, where field notes indicated a minimal, but observable, fluctuation in water levels and pumping rates (Wood, 2007). The combined Cooper-Jacob (1946) and Jacob (1963) method adequately matched drawdown and recovery data, so a grade of " $\mathrm{B}$ " was assigned. Other analyses of the same aquifertest data were graded lower, "C," because drawdowns were interpreted incorrectly by a multiple-parameter solution (Moench, 1984); grades of "D" or "F" were applied for poor or inadequate matches, respectively, to the data for a great number of values.

\section{Slug Tests}

Slug tests investigate smaller volumes of aquifer than do pumping tests; therefore, the highest grade assigned to transmissivity estimates was "B." Assessment of the quality of slug-test analyses is illustrated by the following example. In well $U E-18 r$ (3208-3408 ft), two slug tests were done consecutively, one injection and one swabbing, on February 2, 1968 (fig. 8). No complications were reported in the field for either slug test (Wood 2007), and a second test was likely done because of the lack of full recovery. Seven transmissivities were estimated from responses to the initial injection using five different analytical solutions. Two transmissivities were estimated using inappropriate analytical solutions and were graded "D" because the choice of solutions biased estimates. Four analyses adequately matched the observed recovery, but were graded " $\mathrm{C}$ " because observed recovery was less than 70 percent of the initial static water level. Simultaneous analysis of both slug tests was graded higher, "B," primarily because observed recoveries were consistent and the Bouwer and Rice (1976) model matched the data (fig. 8B). Estimated transmissivity of volcanic rocks open to well UE-18r (3208$3408 \mathrm{ft}$ ) was $1 \mathrm{ft}^{2} /$ day.

Slug-test methods and data could be influenced by confounding factors that increased uncertainty in transmissivity estimates, which were given lower grades. Problems arose when interpreting slug-test results from transmissive wells because the aquifer rapidly equilibrated to the injection of small amounts of water, and the rapid equilibration might not be captured, depending on the frequency of water-level measurements. For example, following a slug-test injection in well $U E-18 r(3442-3642 \mathrm{ft}$ ), approximately 671 feet of water-level recovery was not measured in the first minute after the test was initiated (fig. 6). Water levels declined another $720 \mathrm{ft}$ in the next 4 minutes, and only four water levels were measured. A transmissivity of $80 \mathrm{ft}^{2} /$ day was estimated by the Bouwer and Rice (1976) solution (Frus and Halford, 2018). This slug-test analysis received a grade of " $\mathrm{C}$ " because the analytical model adequately matched the recovery data. Other analyses of these data were given lower grades " $D$ " because of poor goodnessof-fits between analytical models and the data.

Transmissivity estimates were graded " $\mathrm{F}$ " when failed slug tests were analyzed, interpretation resulted in unreasonable storativity estimates, or previous analyses could not be evaluated because of missing files. Slug tests were classified as failed if packer leakage, packer failure, or tubing blockage was reported in the field notes. Transmissivity estimates from multiple-parameter solutions with unreasonable properties assigned to insensitive parameters were graded "F." For example, a slug test in well UE-19i (3646-3804 ft) was interpreted by the Cooper, Bredehoeft, and Papadopoulos (1967) model. A storage coefficient of $10^{-10}$ was estimated, which is physically impossible. Reasonable estimates of storage coefficient ranged between $10^{-5}$ and $10^{-4}$ in well UE-19i (3646-3804 ft).

\section{Single-Well Aquifer-Test Synthesis}

A best transmissivity estimate was reported that was the highest graded analysis for each well (Frus and Halford, 2018). A grade was reported, rather than an average of all aquifer-test analyses for a well, because at least one analysis was graded D or F for more than 80 percent of the 360 wells. Standard deviation of multiple transmissivity estimates for a well was not reported because standard deviation characterizes uncertainty of the analyses, not uncertainty in aquifer transmissivity. Reporting standard deviation also is misleading if at least one aquifer-test analysis is erroneous.

About 20 percent of the best transmissivity estimates were qualified as a minimum or maximum because measurement limitations precluded definitive estimates. Measurement limitations primarily affected transmissivity estimates from slug tests. Minimum transmissivity estimates were reported for 35 wells in which water levels could not be measured with sufficient frequency by a wireline. Maximum transmissivity estimates were reported for 33 wells for which 4-hour recovery periods were insufficient. Minimum transmissivity estimates were reported for pumping tests from 3 of 50 wells because thermal effects obscured drawdown estimates. 

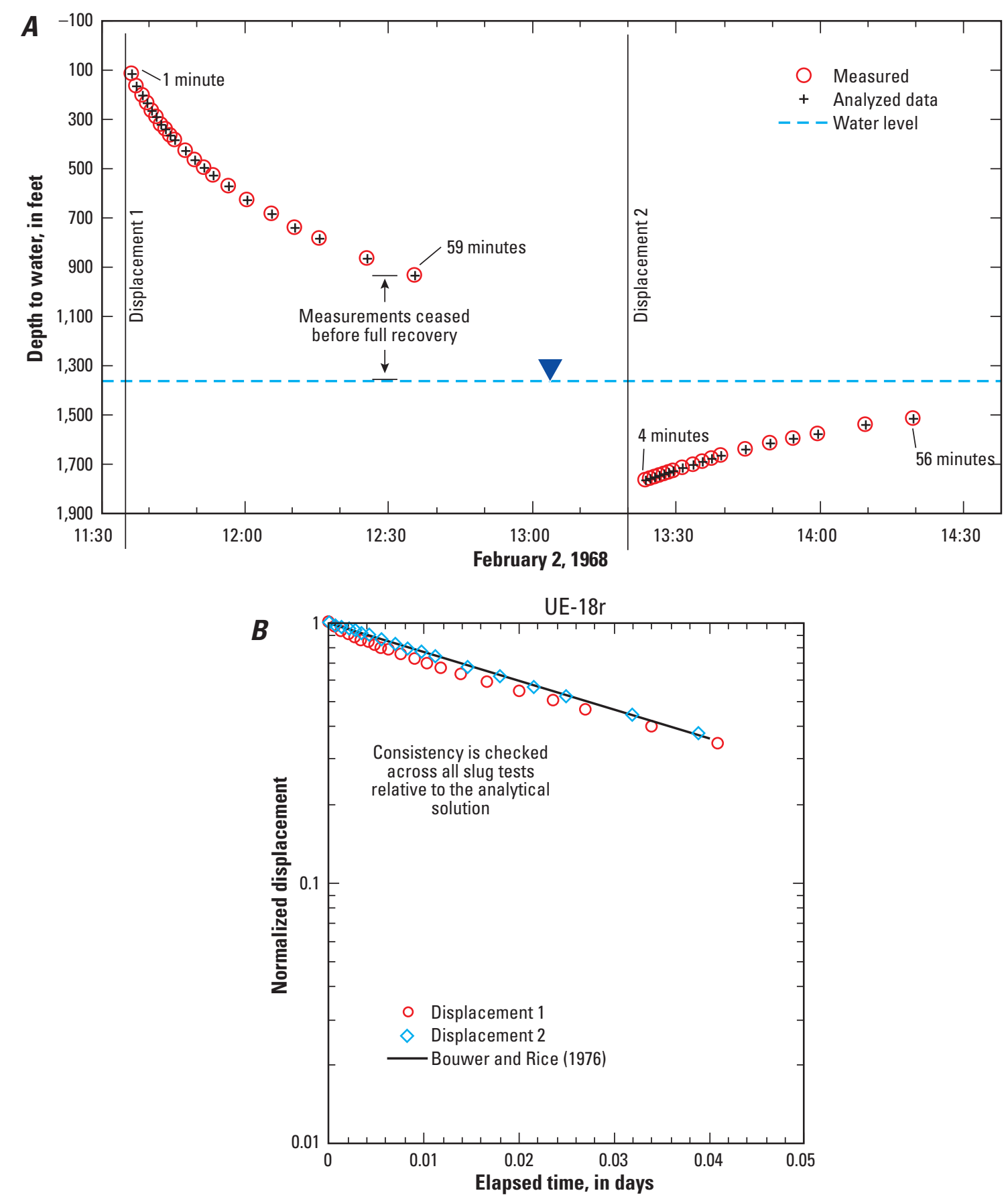

Figure 8. Graphs showing eExample using a Bouwer and Rice (1976) analytical solution to estimate hydraulic properties from consecutive multiple slug tests in well UE-18r (3208-3408 ft), February 2, 1968. A, Cartesian plot of changes in water-level depth through time; $B$, Semi-log plot of normalized displacement for all single-well aquifer-test stresses applied to an individual well. 


\section{Integrated Borehole Analysis}

Results from pumping and slug tests were integrated for 17 wellbores to estimate hydraulic conductivity by depth. Integration reconciles differences between transmissivity from pumping tests and total transmissivity derived from summing the results of multiple straddle-packer slug tests performed at different depth intervals in the same borehole. Transmissivity estimates from pumping tests and summed transmissivity from all slug-test results theoretically should agree, but differ primarily because slug tests cannot quantify transmissivities in highly permeable intervals. Transmissivity estimates from pumping tests exceeded slug-test results by factors of 2 to 800 where total transmissivity exceeded $500 \mathrm{ft}^{2} / \mathrm{d}$ in 14 of 17 boreholes. Differences between transmissivity estimates from pumping tests and summed slug-test results are referred to as excess transmissivity and used to make corrections to hydraulic conductivity estimates from slug tests in permeable intervals (transmissivity generally greater than $550 \mathrm{ft}^{2} / \mathrm{d}$ ).

Drilling and hydraulic testing were done in 2 stages for 5 of 17 boreholes. Total depths of these five boreholes ranged from 7,500 to $13,686 \mathrm{ft}$ below land surface. During the first stage of well completion, these boreholes were drilled to about half their final, total depths and hydraulically tested. A total transmissivity was estimated for the long, open borehole from a pumping test. Straddle packers also were used to isolate open intervals of the wellbore for slug testing. Once hydraulic testing was complete, the boreholes were drilled to their final, total depths, and the lower part of the borehole was hydraulically tested using the same methods.

Permeable intervals in a borehole were identified by minimally raised water levels during injection and by reviewing field notes (Blankennagel, 1967; Blankennagel and Weir, 1973). Water levels typically rose less than $100 \mathrm{ft}$ if average hydraulic conductivity in a packer interval was greater than $0.1 \mathrm{ft} / \mathrm{d}$. For example, water levels rose less than $40 \mathrm{ft}$ in well $U-19 d 2(3285-3483 \mathrm{ft})$ during an injection test (fig. 9). Hydraulic conductivity of $0.13 \mathrm{ft} / \mathrm{d}$ was estimated from the slug test for well $U-19 d 2(3285-3483 \mathrm{ft})$. Average hydraulic conductivities in these permeable intervals were expected to exceed interval-specific estimates because water levels could not be measured with sufficient frequency during slug tests. Field notes on tracer tests and flow logs affirmed permeable flowing fractures within $200 \mathrm{ft}$ of tested intervals. For example, well $U-19 d 2$ (3285-3483 ft) straddles a highpermeability interval from 3,300 to 3,350 ft (Blankennagel and Weir, 1973).
Low-permeability intervals were identified by insufficient recovery during the length of the test, extremely low hydraulic conductivity estimates, and by reviewing field notes (Blankennagel, 1967; Blankennagel and Weir, 1973). A lower detection limit was established for slug tests if hydraulic conductivity estimates were less than $0.02 \mathrm{ft} / \mathrm{day}$. At the lower hydraulic conductivity, it was hard to determine between the geologic formation responding to the stress and the packer unit leaking. An example of a leaky packer was identified in field notes for well $U E-20 d(4118-4316 \mathrm{ft}$ ), which indicated that the lower packer was bypassed, and therefore, the results were considered to be less than the estimated $19 \mathrm{ft} / \mathrm{d}$ (Wood, 2007).

A single hydraulic conductivity estimate was added to all identified permeable intervals in a borehole to include the excess transmissivity calculated for that borehole. Added hydraulic conductivity was calculated as excess transmissivity divided by the length of the sum of permeable intervals in the borehole. Between 0 and 4 permeable intervals were encountered in each borehole, and 13 of 17 boreholes had 2 or fewer permeable intervals. Permeable intervals cumulatively totaled $6,900 \mathrm{ft}$ in the $74,800 \mathrm{ft}$ of saturated borehole that was tested. Intervals of flowing fractures, as measured with flow logs and injection tests, averaged $40 \mathrm{ft}$ thick and ranged between 10 and $70 \mathrm{ft}$ thick (Blankennagel and Weir, 1973). Assuming permeable intervals for slug tests had approximately $40 \mathrm{ft}$ of flowing fractures in each $200 \mathrm{ft}$ interval, flowing fractures accounted for about $1,380 \mathrm{ft}$ ( 20 percent) of the $6,900 \mathrm{ft}$ classified as permeable intervals. Most permeability, therefore, would be in about 2 percent of the $74,800 \mathrm{ft}$ of saturated borehole tested.

Integrated borehole analysis results were reported for all 17 boreholes in an interactive Microsoft Excel ${ }^{\mathbb{}}$ workbook (Frus and Halford, 2018). Open intervals of borehole, tested intervals, hydrostratigraphic units, range of water levels during slug tests, hydraulic-conductivity estimates, and cumulative transmissivity were presented for each borehole so that results could be viewed in context (fig. 9). Hydrostratigraphic units were sampled from the Phase II hydrostratigraphic framework model of the Pahute Mesa Oasis Valley area (Tim Vogt, Navarro, written commun., 2014). Minimum and maximum depth to water during slug tests were reported and were similar in permeable intervals. Direct and consistent hydraulic conductivities from slug tests and with added hydraulic conductivity from pumping test were reported for each interval. Cumulative transmissivity sums depth-dependent transmissivity from 0 at the bottom of the borehole to total transmissivity at the water table and approximated the depth profile of a flow $\log$ (fig. 9). 


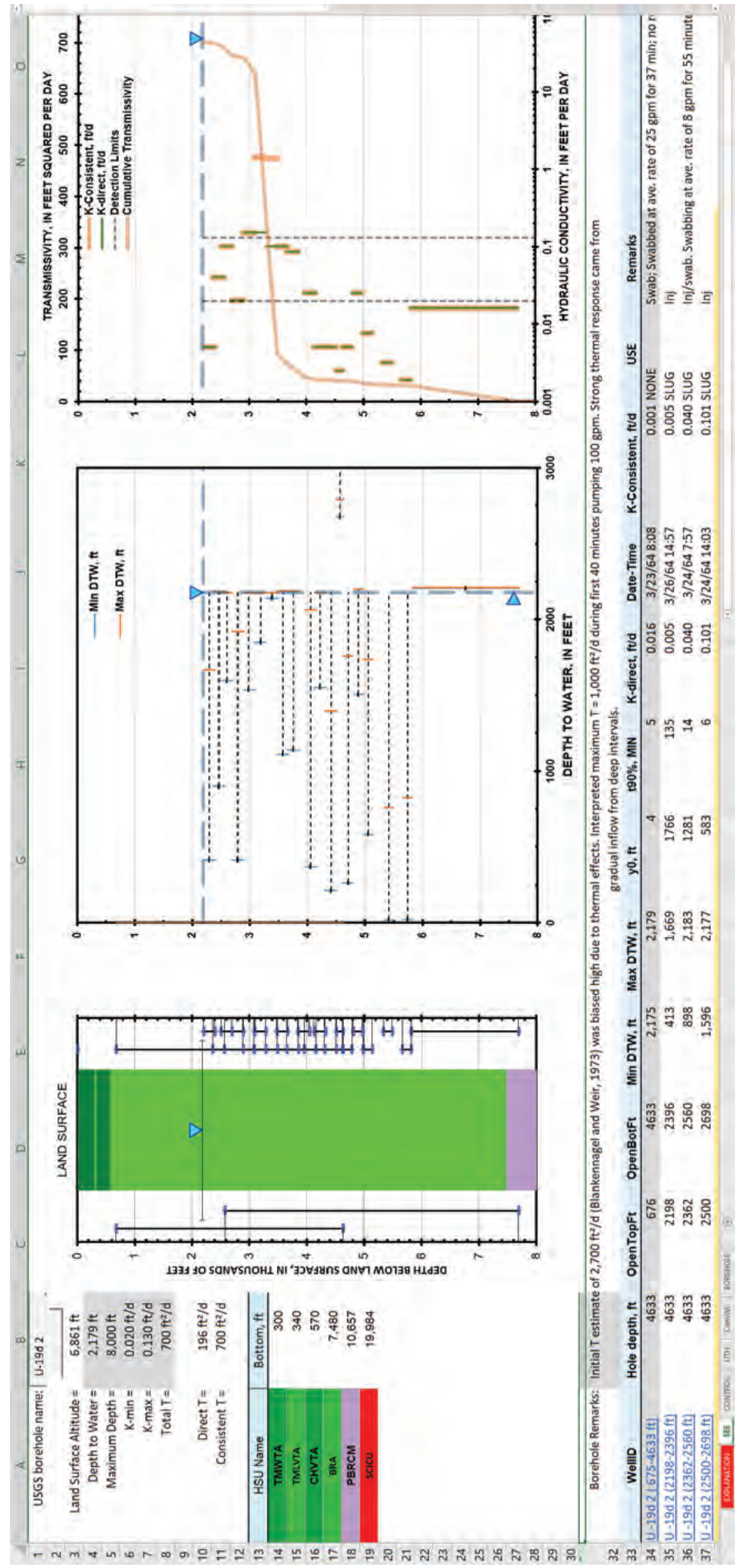

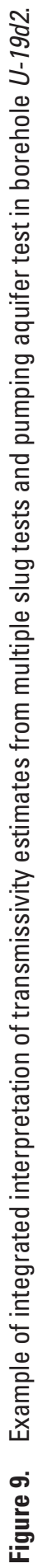




\section{Conclusions}

A hydraulic-parameter database was created to synthesize previously reported single-well aquifer-test results from wells at Pahute Mesa and vicinity. The database defines a well as a single, temporary or permanent, completion in a borehole. For each well (or open interval) tested in a borehole, aquifertest data and supporting single-well aquifer-test analyses were compiled and quality assured to identify the best transmissivity estimate for each well. Aquifer-test analyses were evaluated by the following criteria: aquifer-test type, variability in water-level data, variability in discharge data, confounding factors in the data or associated field notes, and appropriateness of the analytical solution selected. The database includes 360 wells, which have been assigned a unique site identifier referenced to the US Geological Survey National Water Information System database. For each well in the database, aquifer-test datasets, analyses, and transmissivity estimates are presented and graded from A to F. The grades are explained with remarks in the database for the 1,459 singlewell aquifer-test analyses.

An integrated borehole database was created that integrates aquifer-test results from 17 boreholes to estimate hydraulic conductivity according to depth in Pahute Mesa. The integrated analyses reconcile differences between transmissivity estimated from pumping tests and summed transmissivity from straddle-packer slug tests done at different depth intervals in the borehole. The database presents open intervals of the borehole, tested intervals, hydrostratigraphic units, the range of water levels during slug tests, hydraulicconductivity estimates, and cumulative transmissivity for each borehole.

\section{References Cited}

Barker, J.A., 1988, A generalized radial flow model for hydraulic tests in fractured rock: Water Resources Research, v. 24, no. 10, p. 1796-1804, https://agupubs.onlinelibrary. wiley.com/doi/pdf/10.1029/WR024i010p01796.

Belcher, W.R. (ed.), 2004, Death Valley regional groundwater flow system, Nevada and California-Hydrogeologic framework and transient ground-water flow model: U.S. Geological Survey Scientific Investigations Report 2004-5205, 408 p., accessed October 2017 at https://pubs.er.usgs.gov/publication/sir20045205.

Belcher, W.R., Elliott, P.E., and Geldon, A.L., 2001, Hydraulic-property estimates for use with a transient ground-water flow model of the Death Valley regional ground-water flow system, Nevada and California: U.S. Geological Survey Water-Resources Investigations Report 2001-4210, 28 p., accessed August 2017 at https://pubs.er.usgs.gov/publication/wri014210.
Belcher, W.R., Sweetkind, D.S., and Elliott, P.E., 2002, Probability distributions of hydraulic conductivity for the hydrogeologic units of the Death Valley regional ground-water flow system, Nevada and California: U.S. Geological Survey Water-Resources Investigations Report 2002-4212, 18 p., accessed August 2017 at https://pubs.er.usgs.gov/publication/wri024212.

Blankennagel, R.K., 1967, Hydraulic testing techniques of deep drill holes at Pahute Mesa, Nevada test site: U.S. Geological Survey Open-File Report 67-18, 51 p., accessed June 2017 at https://pubs.er.usgs.gov/publication/ofr6718.

Blankennagel, R.K., and Weir, J.E., Jr., 1973, Geohydrology of the eastern part of Pahute Mesa, Nevada Test Site, Nye County, Nevada: U.S. Geological Survey Professional Paper 712-B, 34 p., accessed June 2017 at https://pubs.er.usgs.gov/publication/pp712B.

Bouwer, H., and Rice, R.C., 1976, A slug test for determining hydraulic conductivity of unconfined aquifers with completely or partially penetrating wells: Water Resources Research, v. 12, no. 3, p. 423-428, https://doi.org/10.1029/WR012i003p00423.

Butler, J.J., Jr., 1988, Pumping tests in nonuniform aquifers - The radially symmetric case: Journal of Hydrology, v. 101, no. 1-4, p. 15-30, https://doi.org/10.1016/0022-1694(88)90025-X.

Butler, J.J., Jr., and Garnett, E.J., 2000, Simple procedures for analysis of slug tests in formations of high hydraulic conductivity using spreadsheet and scientific graphics software: Kansas Geological Survey Open-File Report 2000-40, http://www.kgs.ku.edu/Hydro/Publications/OFR00_40/.

Cooper, H.H., Jr., Bredehoeft, J.D., and Papadopulos, I.S., 1967, Response of a finite-diameter well to an instantaneous charge of water: Water Resources Research, v. 3, no. 1, p. 263-269, https://doi.org/10.1029/WR003i001p00263.

Cooper, H.H., Jr., and Jacob, C.E., 1946, A generalized graphical method for evaluating formation constants and summarizing well-field history: Transactions of the American Geophysical Union, v. 27, no. IV, p. 526-534, https://doi.org/10.1029/TR027i004p00526.

Dougherty, D.E., and Babu, D.K., 1984, Flow to a partially penetrating well in a double-porosity reservoir: Water Resources Research, v. 20, no. 8, p. 1116-1122, https://doi.org/10.1029/WR020i008p01116.

Elliott, P.E., and Fenelon, J.M., 2010, Database of groundwater levels and hydrograph descriptions for the Nevada test site area, Nye County, Nevada: U.S. Geological Survey Data Series 533, 16 p., accessed January 2017 at https://pubs.er.usgs.gov/publication/ds533. 
Fenelon, J.M., Halford, K.J., and Moreo, M.T., 2016, Delineation of the Pahute Mesa-Oasis Valley groundwater basin, Nevada: U.S. Geological Survey Scientific Investigations Report 2015-5175, 40 p., accessed August 2016 at https://pubs.er.usgs.gov/publication/sir20155175.

Fetter, C.W., 2001, Applied Hydrogeology: New Jersey, Prentice Hall, 615 p.

Frus, R.J., and Halford, K.J., 2018, Data release for singlewell aquifer tests and integrated borehole analyses, Pahute Mesa and Vicinity, Nevada: U.S. Geological Survey Data Release, https://doi.org/10.5066/P9CF9QKZ.

Garcia, C.A., Fenelon, J.M., Halford, K.J., Reiner, S.R., and Laczniak, R.J., 2011, Assessing hydraulic connections across a complex sequence of volcanic rocks-Analysis of U-20 WW multiple-well aquifer test, Pahute Mesa, Nevada National Security Site, Nevada: U.S. Geological Survey Scientific Investigations Report 2011-5173, 24 p., accessed August 2017 at https://pubs.er.usgs.gov/publication/sir20115173.

Garcia, C.A., Jackson, T.R., Halford, K.J., Sweetkind, D.S., Damar, N.A., Fenelon, J.M., and Reiner, S.R., 2017, Hydraulic characterization of volcanic rocks in Pahute Mesa using an integrated analysis of 16 multiple-well aquifer tests, Nevada National Security Site, 2009-14: U.S. Geological Survey Scientific Investigations Report 2016-5151, 61 p., accessed August 2017 at https://pubs.er.usgs.gov/publication/sir20165151.

Gringarten, A.C., Ramey, H.J., Jr., and Raghavan, R., 1974, Unsteady-state pressure distributions created by a well with a single infinite-conductivity vertical fracture: Society of Petroleum Engineers Journal, v. 14, no. 4, 14 p., https://doi.org/10.2118/4051-PA.

Halford, K.J., Laczniak, R.J., and Galloway, D.L., 2005, Hydraulic characterization of overpressured tuffs in central Yucca Flat, Nevada Test Site, Nye County, Nevada: U.S. Geological Survey Scientific Investigations Report 2005-5211, 55 p., accessed August 2017 at https://pubs.er.usgs.gov/publication/sir20055211.

Halford, K.J., Weight, W.D., and Schreiber, R.P., 2006, Interpretation of transmissivity estimates from single-well pumping aquifer tests: Groundwater, v. 44, no. 3, p. 467471, https://doi.org/10.1111/j.1745-6584.2005.00151.x.

Hantush, M.S., and Jacob, C.E., 1955, Steady threedimensional flow to a well in a two-layered aquifer: Transactions of the American Geophysical Union, v. 36 , no. 2, p. 286-292, https://doi.org/10.1029/TR036i002p00286.
Hvorslev, M.J., 1951, Time lag and soil permeability in ground-water observations: Waterways Experiment Station, U.S. Corps of Engineers, Vicksburg, Miss. Bulletin 36, 57 p., http://acwc.sdp.sirsi.net/client/en_US/default/index. assetbox.assetactionicon.view/1004497/?rm=GENERAL+ REPORTS0\%7C \%7C \%7C1\%7C \%7C \%7C0\%7C\%7C\%7C true.

Hyder, Z., Butler, J.J., Jr., McElwee, C.D., and Liu, W., 1994, Slug tests in partially penetrating wells: Water Resources Research, v. 30, no. 11, p. 2945-2957, https://doi.org/10.1029/94WR01670.

IT Corporation, 1998, Report and analysis of the BULLION forced-gradient experiment: IT Corporation Report DOE/NV/13052-042, 190 p., https://www.osti.gov/servlets/purl/305939.

IT Corporation, 2002, Analysis of well ER-EC-1 testing, western Pahute Mesa-Oasis Valley FY 2000 testing program: IT Corporation Report DOE/NV/13052-846, 200 p., https://www.osti.gov/servlets/purl/1186685.

Jacob, C.E., 1963, The recovery method for determining the coefficient of transmissibility, in Bentall, R., ed., Methods of determining permeability, transmissibility, and drawdown: U.S. Geological Survey WaterSupply Paper 1536-I, p. 283-292, https://pubs.er.usgs.gov/publication/wsp1536I.

Kilroy, K.C., and Savard, C.S., 1996, Geohydrology of Pahute Mesa-3 test well, Nye County, Nevada: U.S. Geological Survey Water-Resources Investigations Report 95-4239, 37 p., accessed January 2018 at https://pubs.er.usgs.gov/publication/wri954239.

Konikow, L.F., 2010, The secret to successful solute-transport modeling: Groundwater, v. 49, no. 2, p. 144-159, https://doi.org/10.1111/j.1745-6584.2010.00764.x.

Mirus, B.B., Halford, K.J., Sweetkind, D., Fenelon, J.M., 2016, Testing the suitability of geologic frameworks for extrapolating hydraulic properties across regional scales: Hydrogeology Journal, v. 24, no. 5, p. 1133-1146, https://doi.org/10.1007/s10040-016-1375-1.

Moench, A.F., 1984, Double-porosity models for a fissured groundwater reservoir with fracture skin: Water Resources Research, v. 20, no. 7, p. 831-846, https://doi.org/10.1029/WR020i007p00831.

Moench, A.F., 1985, Transient flow to a large-diameter well in an aquifer with storative semiconfining layers: Water Resources Research, v. 21, no. 8, p. 1121-1131, https://doi.org/10.1029/WR021i008p01121. 
Neuman, S.P., 1974, Effect of partial penetration on flow in unconfined aquifers considering delayed gravity response: Water Resources Research, v. 10, no. 2, p. 303-312, https://doi.org/10.1029/WR010i002p00303.

Papadopulos, I.S., and Cooper, H.H., Jr., 1967, Drawdown in a well of large diameter: Water Resources Research, v. 3, no. 1, p. 241-244, https://doi.org/10.1029/WR003i001p00241.

Reiner, S.R., 2007, Ground-water temperature data, Nevada test site and vicinity, Nye, Clark, and Lincoln counties, Nevada, 2000-2006: U.S. Geological Survey Data Series 269, 21 p., accessed August 2017 at https://pubs.er.usgs.gov/publication/ds269.

Reiner, S.R., Laczniak, R.J., DeMeo, G.A., Smith, J.L., Elliott, P.E., Nylund, W.E., and Fridrich C.J., 2002, Ground-water discharge determined from measurements of evapotranspiration, other available hydrologic components, and shallow water-level changes, Oasis Valley, Nye County, Nevada: U.S. Geological Survey Water-Resources Investigations Report 2001-4239, 65 p., accessed March 2018 at https://pubs.er.usgs.gov/publication/wri014239.

Sawyer, D.A., Fleck, R.J., Lanphere, M.A., Warren, R.G., Broxton, D.E., and Hudson, M.R., 1994, Episodic caldera volcanism in the Miocene southwestern Nevada volcanic field-Revised stratigraphic framework, ${ }^{40} \mathrm{Ar} /{ }^{39} \mathrm{Ar}$ geochronology, and implications for magmatism and extension: Geological Society of America Bulletin, v. 106, no. 10, p. 1304-1318, https://pubs.geoscienceworld.org/gsa/ gsabulletin/article/106/10/1304-1318/182886.

Soulé, D.A., 2006, Climatology of the Nevada Test Site: Special Operations and Research Division Technical Memorandum SORD 2006-3, 171 p., accessed September 2017 at http://www.sord.nv.doe.gov/documents/ Climatology_of_The_Nevada_Test_Site.Soule.pdf.

Stallman, R.W., 1971, Aquifer-test design, observation, and data analysis: U.S. Geological Survey Techniques of Water-Resources Investigations 03-B1, 26 p., accessed August 2017 at https://pubs.er.usgs.gov/publication/twri03B1.

State of Nevada, U.S. Department of Energy, and U.S. Department of Defense, 1996, Federal facility agreement and consent order (FFACO), 1021 p., accessed February 2018 at https://ndep.nv.gov/uploads/land-doeffaco-docs/2018_FFACO.pdf.
Stoller-Navarro Joint Venture, 2004, Hydrologic data for the groundwater flow and contaminant transport model of corrective action units 101 and 102 - Central and Western Pahute Mesa, Nye County, Nevada: Stoller-Navarro Joint Venture Report S-N/99205-002, 422 p., accessed June 2018 at http://water.nv.gov/hearings/past/Spring $\% 20$ Valley $\% 20$ 2006/exhibits/SNWA/4_Hydrology/Groundwater/Data/2Hydraulic_properties/5-Selected-Reports/DOE-ER-Reports/ SNJV-2004a-Hydro_Data_PM.pdf.

Sweetkind, D.S., Dickerson, R.P., Blakely, R.J., and Denning, P.D., 2001, Interpretive geologic cross sections for the Death Valley regional flow system and surrounding areas, Nevada and California: U.S. Geological Survey Miscellaneous Field Studies Map 2370, three sheets, 35 p., accessed at https://pubs.er.usgs.gov/publication/mf2370.

Theis, C.V., 1935, The relation between the lowering of the Piezometric surface and the rate and duration of discharge of a well using ground-water Storage: Transactions of the American Geophysical Union, v. 16, no. 2, p. 519-524, https://doi.org/10.1029/TR016i002p00519.

Thomasson, H.G., Jr., Olmsted, F.H., and LeRoux, E.F., 1960, Geology, water resources and usable groundwater storage capacity of part of Solano County, California: U.S. Geological Survey Water Supply Paper 1464, 693 p., accessed August 2017 at https://pubs.er.usgs.gov/publication/wsp1464.

U.S. Department of Energy, 2015, United States nuclear tests, July 1945 through September 1992: U.S. Department of Energy Report DOE/NV-209-REV 16, 129 p., accessed March 8, 2018, at https://www.nnss.gov/docs/docs_ LibraryPublications/DOE_NV-209_Rev16.pdf.

Winograd, I.J., and Thordarson, W., 1975, Hydrogeologic and hydrochemical framework, south-central Great Basin, Nevada-California, with special reference to the Nevada Test Site: U.S. Geological Survey Professional Paper 712-C, 125 p., accessed May 7, 2018, at https://pubs.er.usgs.gov/publication/pp712C.

Wood, D.B., 2007, Digitally available interval-specific rocksample data compiled from historical records, Nevada National Security Site and vicinity, Nye County, Nevada: U.S. Geological Survey Data Series 297, 23 p., https://doi.org/10.3133/ds297.

Yager, R.M., Maurer, D.K., and Mayers, C.J., 2012, Assessing potential effects of changes in water use with a numerical groundwater-flow model of Carson Valley, Douglas County, Nevada, and Alpine County, California: U.S. Geological Survey Scientific Investigations Report 2012-5262, 84 p., accessed August 2017 at https://pubs.er.usgs.gov/publication/sir20125262. 
Prepared by the Sacramento Publishing Service Center.

For more information concerning this report, contact:

Director

U.S. Geological Survey

Nevada Water Science Center

2730 N. Deer Run Rd.

Carson City, NV 89701

dc_nv@usgs.gov

Or, visit our Web site at:

http://nevada.usgs.gov/water/ 


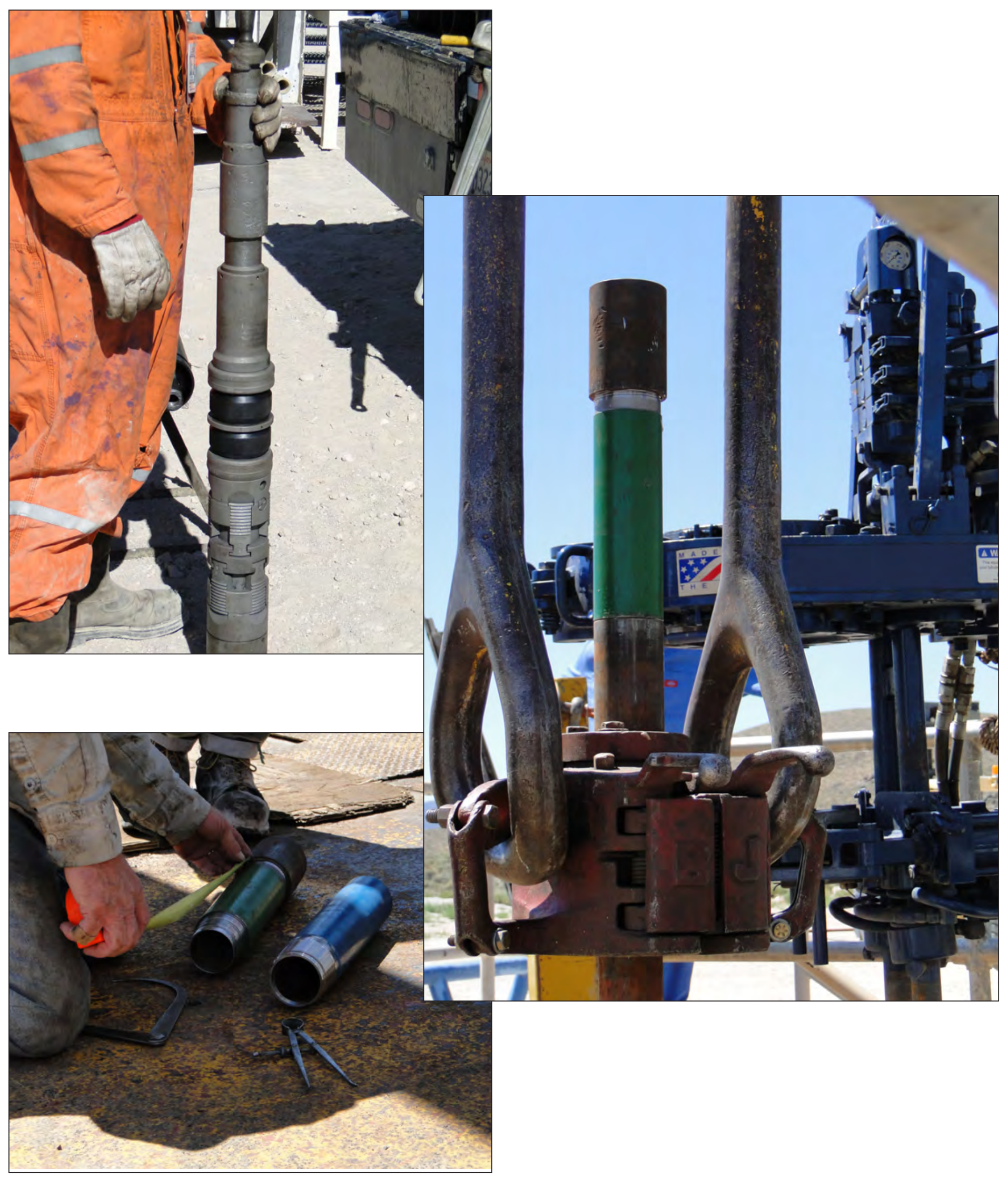

